\title{
CHAPTER VI
}

\section{$\mathbb{A} \mathbb{Q} \mathbb{A} \mathbb{T} \mathbb{C} \quad S \mathbb{C} \mathbb{C} \mathbb{E} \mathbb{T} \mathbb{E} S$}

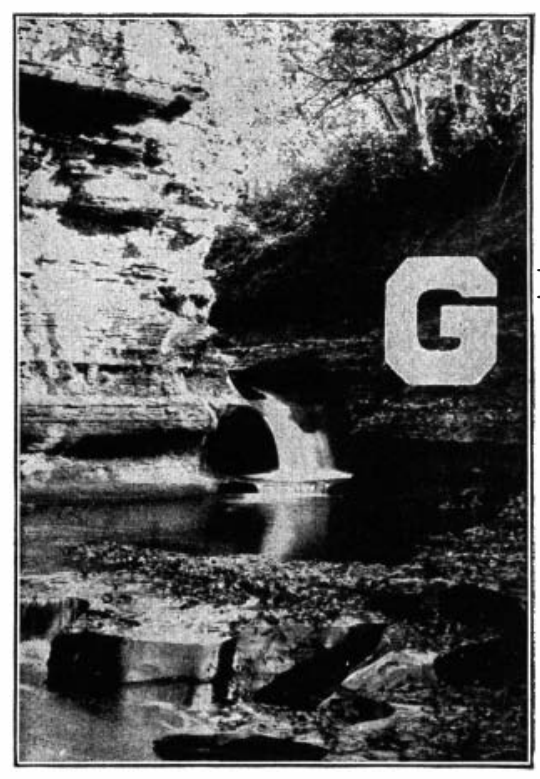

\section{$\mathbb{L} \mathbb{M} \mathbb{N} \mathbb{E} \mathbb{I} C$ $S \mathbb{C} \mathbb{I} \mathbb{E} \mathbb{T} \mathbb{E}$}

REAT bodies of water furnish opportunity for all the different lines of adaptation discussed in the preceding chapter. The sun shines full upon them in all its life-giving power. The rivers carry into them the dissolved food substances from the land. Wind and waves and convection currents discribute these substances throughout their waters. Both the energy and the food needed for the maintenance of life are everywhere present. Here are expanses of open water for such organisms as can float or swim. Here are shores for such as must find shelter and resting places; shores bare and rocky; shores low and sandy; shores sheltered and muddy, with bordering marshes and with inflowing streams. The character of the population in any place is determined primarily by the fitness of the organisms for the conditions they have to meet in it. 
For every species the possible range is determined by climate; the possible habitat, by distribution of water and land; the actual habitat, by the presence of available food and shelter, and by competitors and enemies.

Our classification of aquatic societies finds its basis in physiographic conditions. We recognize two principal ecological categories of aquatic organisms:

I. Limnetic Societies, fitted for life in the open water, and able to get along in comparative independence of the shores.

II. Littoral Societies, of shoreward and inland distribution.

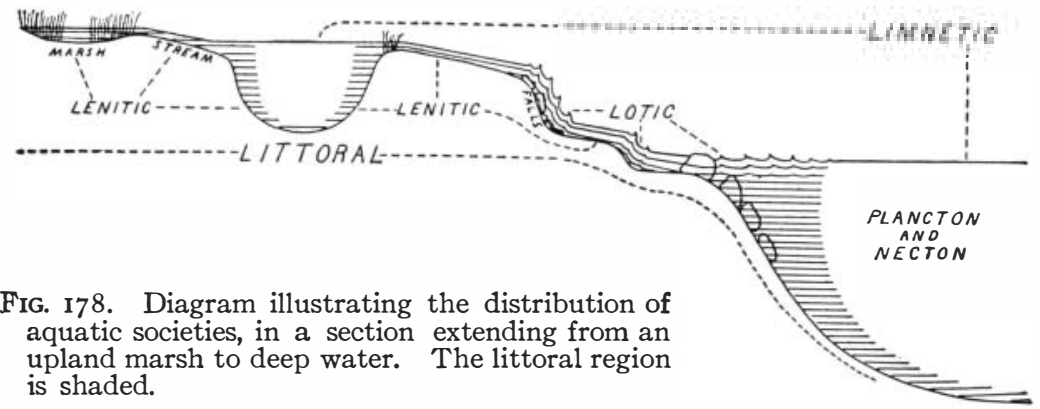

The life of the open water of lakes includes very small and very large organisms, with a noteworthy scarcity of forms of intermediate size. It is rather sharply differentiated into plancton and necton; into small and large; into free-floating and free-swimming forms. These have been mentioned in Chapter V, where their main lines of adaptation were pointed out. It remains to indicate something of the composition and relations of these ecological groups. 


\section{PLANCTON}

If one draw a net of fine silk bolting-cloth through the clear water of the open lake, where no life is visible, he will soon find that the net is straining something out

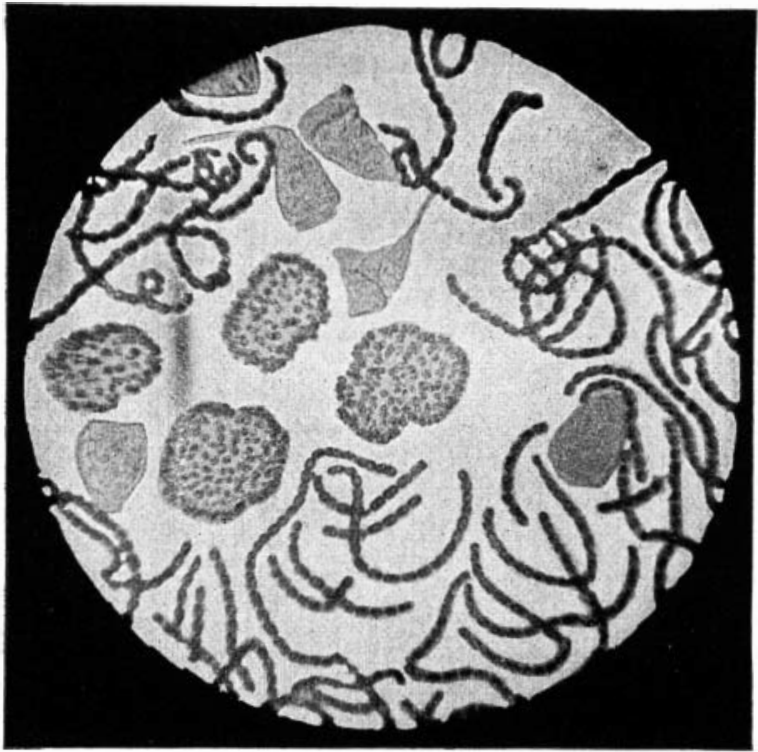

FIG. I 79. "Water bloom" from the surface of Cayuga Lake. The curving filaments are algæ of the genus Anabæna. The stalked animalcules attached to the filaments are Vorticellas. The irregular bodies of small flagellate cells, massed together in soft gelatine, are Uroglenas.

of the water. If he shake down the contents and lift the net from the water he will see covering its bottom a film of stuff of a pale yellowish green or grayish or brownish color, having a more or less fishy smell, and a gelatinous consistency. If he drop a spoonful of this freshly gathered stuff into a glass of clear water and 
hold it toward the light, he will see it diffuse through the water, imparting a dilution of its own color; and in the midst of the flocculence, he will see numbers of minute animals swimming actively about. Little can be seen in this way, however. But if he will examine a drop of the stuff from the net bottom under the microscope, almost a new world of life will then stand revealed.

It is a world of little things; most of them too small to be seen unless magnified; most of them so transparent that they escape the unaided eye. Here are both plants and animals; producers and consumers; plants with chlorophyl, and plants that lack it; also, parasites and scavengers. And it is all adrift in the open waters of the lake.

Tho plancton-organisms are so transparent and individually so small, they sometimes accumulate in masses upon the surface of the water and thus become conspicuous as "water bloom." A number of the filamentous blue-green algæ, such as Anabæna, fig. I79, and a few flagellates, accumulate on the surface during periods of calm, hot weather. Anabæna rises in August in Cayuga Lake, and Euglena rises in June in the backwaters adjacent to the Lake (see fig. I, on page I 5).

The plants of the plancton are mainly algæ. Bacteria and parasitic fungi are ever present, though of little quantitative importance. They are, of course, important to the sanitarian. Of the higher plants there are none fitted for life in the open water; but such of their products as spores and pollen grains occur adventitiously in the plancton. It is the simply organized algæ that are best able to meet the conditions of openwater life. These constitute the producing class. These build up living substance from the raw materials offered by the inorganic world, and on these the life of 
all the animals of both the plancton and the necton, depends.

These are diatoms, blue-green and true-green algæ, and chlorophyl-bearing flagellates. Concerning the limnetic habits of the last named group, we have spoken briefly in Chapter IV (pp. I02-I08). Being equipped with flagella, they are nearly all free-swimming. Most important among them are Ceratium, Dinobryon and Peridinium.

Most numerous in individuals of all the plancton algæ, and most constant in their occurrence throughout the year, are the diatoms (see fig. 35 on p. I I I). Wherever and whenever we haul a plancton net in the open waters of river, lake or pond, we are pretty sure to get diatoms in the following forms of aggregation:

I. Flat ribbons composed of the thin cells of Diatoma, Fragillaria, and Tabelaria.

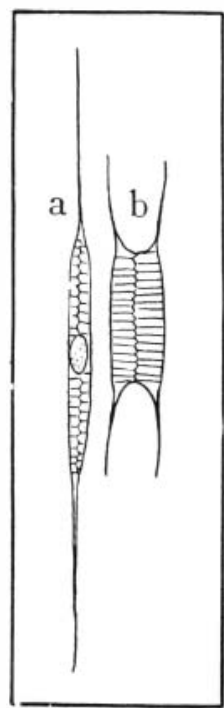

FIG. I 80.

a, Rhizosolenia;

$o$, Attheya.

2. Cylindric filaments composed of the drum-shaped bodies of Melosira and Cyclotella.

3. Radiating colonies of Asterionella.

4. Slender single cells of Synedra.

And we may get less common forms showing such diverse structures for flotation as those of Stephanodiscus (fig. $35 I$ ) and Rhizosolenia (fig. I 80); or we may get such predominantly shoreward forms as Navicula and Meridion.

The blue-green algæ of the plancton are very numerous and diverse, but the more common limnetic forms are these:

I. Filamentous forms having:

(a) Stiff, smoothly-contoured filaments; Oscillatoria (see fig. 34 on p. I09) and Lyngbya, etc.

(b) Sinuous nodose filaments, Anabæna (fig. I79), Aphanizomenon, etc. 


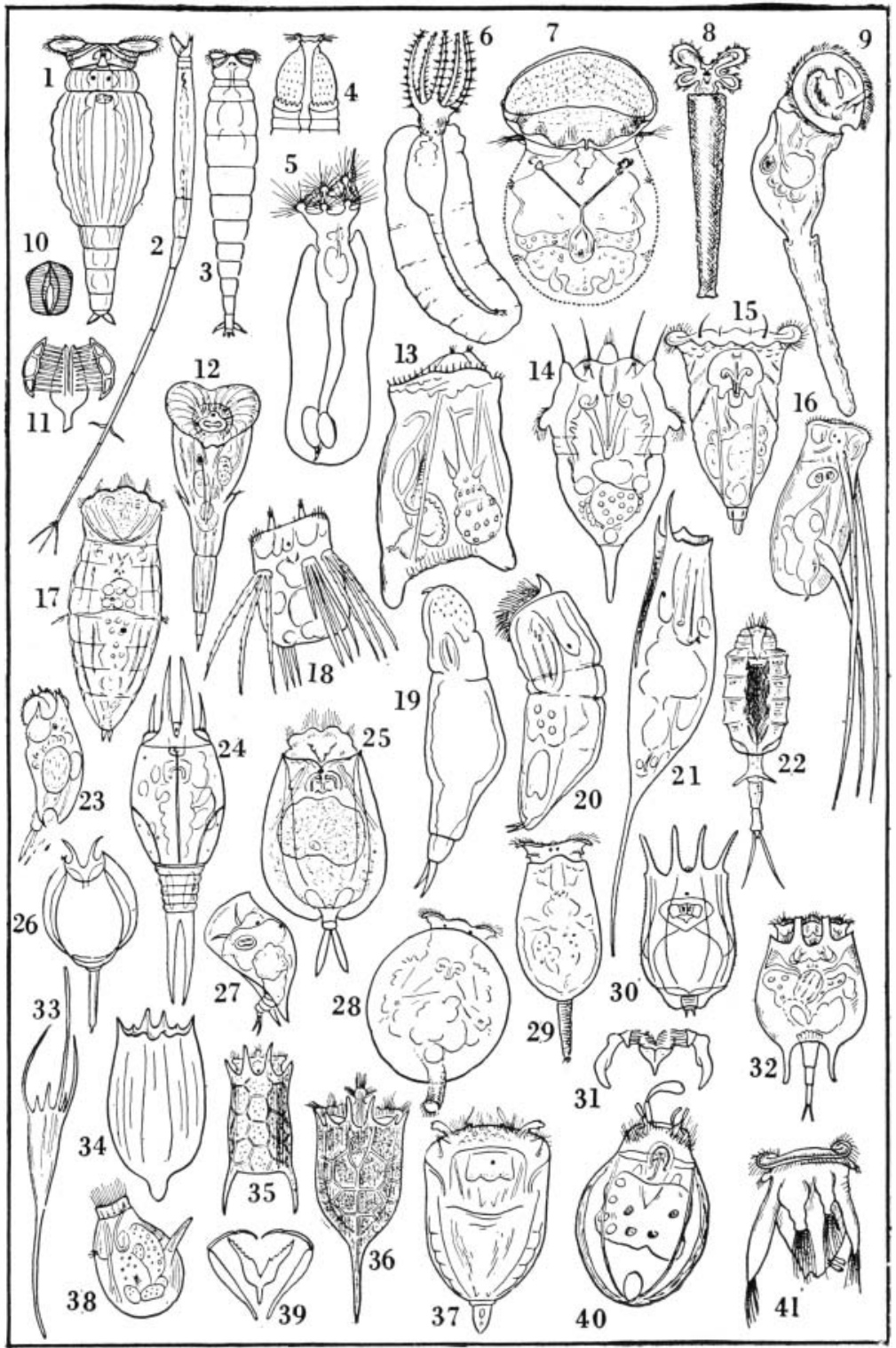

F IG. I8I. Rotifers. 
(c) Tapering filaments that are immersed in more or less spherical masses of gelatine, their points radiating outward; Gloiotrichia, Rivularia (see fig. $5 \mathrm{I}$, on p. I33, and 52), etc.

2. Non-filamentous forms having:

(a) Cells immersed in a mass of gelatine, Microcystis (including Polycystis and Clathrocystis, see fig. 5I on p. I33), Cœlosphærium, Chroococcus, etc,

b) Cells arranged in a thin flat plate. Tetrapedia (fig. 5I), Merismopædia (see fig. 53 on p. I35), etc.

Representatives of all these groups, except the one last named, become at times excessively abundant in lakes and ponds, and many of them appear on the surface as "water bloom."

Of the green algæ there are a few not very common but very striking forms of rather large size found in the plancton. Such are Pediastrum (see fig. 44 on p. I23) and the desmid, Staurastum. There are many minute green algæ of the utmost diversity in form and arrangement of cells. Most of those that are shown in figure 50 on page I 29 occur in the plancton; Botyrococcus is the most conspicuous of these. A few filamentous green forms such as Conferva (see fig. 45 on p. I24) and the Conjugates (fig. 4I on p. I I9), occur there adventitiously, their centers of development being on shores.

The animals of the plancton are mainly protozoans, rotifers and crustaceans. The protozoans of the open

FIG. I 8 I.

I, Philodina. 2, 3, Rotifer. 4, Adineta. 5, Floscularia. 6, Stephanoceros. 7, Apsilus. 8, Melicerta. 9, Conochilus. Io, Ramate jaws. II, Malleo-ramate jaws. I2, Microcodon. I3, Asplanchna. I4, 15, Synchæta. 16, Triarthra. I7, Hydatina. I8, Polyarthra. I9, Diglena. 20, D urella, 21 , Rattulus. 22, Dinocharis. 23, 24, Salpina. 25. Euchlanis. 26, Monostyla. 27, Colurus. 28, 29, Pterodina. 30. Brachionus. 3I, Malleate jaws. 32, Noteus. 33, 34, Notholca. 35, 36, Anuraea. 37, Plœsoma. 38, Gastropus. 39. Forcipate jaws. 40, Anapus. 42, Pedalion.

From Genera of Plancton Organisms of the Cayuga Lake Basin, by O. A. Johannsen and the junior author. 
water are few. If we leave aside the chlorophylbearing flagellates already mentioned (often considered to be protozoa) the commoner forms among them are such other flagellates as Mallomonas (see fig. I 85 on page 309), such sessile forms as Vorticella (fig. I79)

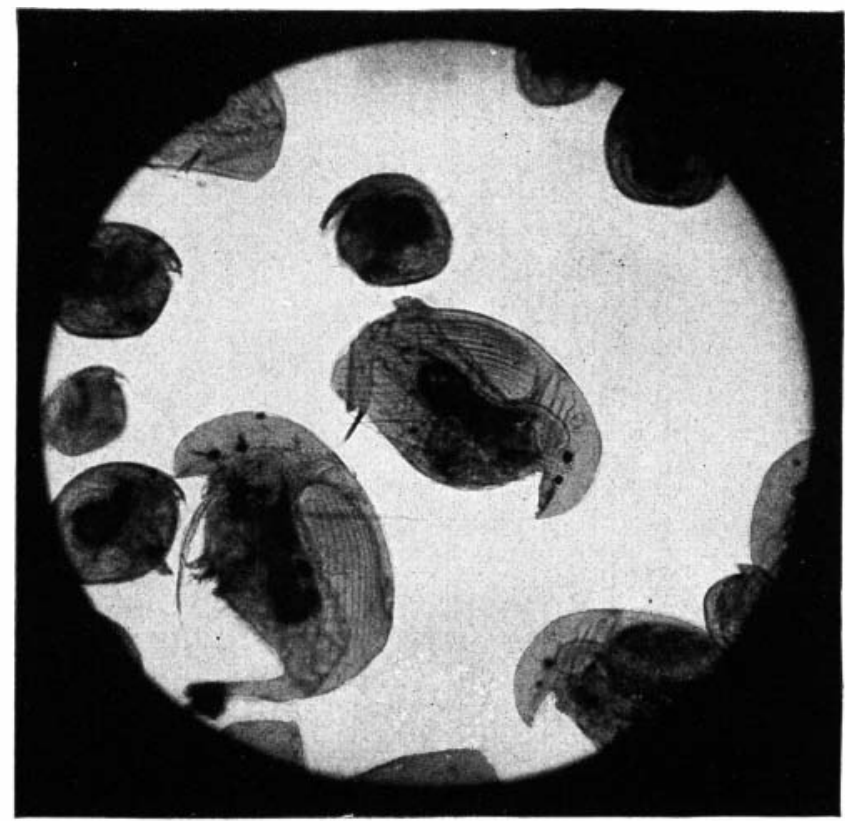

FIG. I82. Plancton Cladocerans from Cayuga Lake, The larger, Acroperus harpre; the smaller, Chydorus sp.

and such shell-bearing forms as Arcella and Difflugia (see fig. 69 on p. I59).

The rotifers of the plancton are many. The most strictly limnetic of these are little loricate forms such as Anuraea and Notholca, two or three species of each genus. When one looks at his catch through a microscope nothing is commoner than to see these little thin- 
shelled animals tumbling indecorously about. Sometimes almost every female will be carrying a single large egg. Several larger limnetic rotifers, such as Triarthra, Polyarthra and Pedalion, bear conspicuous appendages by which they may be easily recognized. The softerbodied Synchæta will be recognized by the pair of earlike prominences at the front. Other common limnetic forms are shown at 2 (Rotifer neptunius), 2 I and 25 of figure I $8 \mathrm{I}$.

The crustacea of fresh-water plancton are its largest organisms. They are its greatest consumers of vegetable products. They are themselves its greatest contribution to the food of fishes. Most of them are herbivorous, a few eat a mixed diet of algæ and of the smaller animals. The large and powerful Leptodora is strictly carnivorous. The following are the more truly limnetic forms:

I. Cladocerans; species of

Daphne (fig. 234)

Chydorus

Bosmina (fig. 9I)

Sida

Acroperus (fig. I 82)

Diaphanosoma

Ceriodaphnia (fig. I65)

Polyphemus

Bythotrephes

Leptodora. (fig. I 86)

II. Copepods; species of Cyclops

Diaptomus

Epischura

Limnocalanus

Canthocamptus (see figures 95 and 96)

Of plancton animals other than those of the groups above discussed, there are no limnetic forms of any great importance. There is one crustacean of the Malacostracan group, Mysis relicta, that occurs in the deeper waters of the great lakes. There is one transparent water-mite, Atax crassipes, with unusually long 
and well fringed swimming legs, that may fairly be counted limnetic. There is only one limnetic insect. It is the larva of Corethra-a very transparent, free swimming larva, having within its body two pairs of air sacs that are doubtless regulators of its specific gravity.

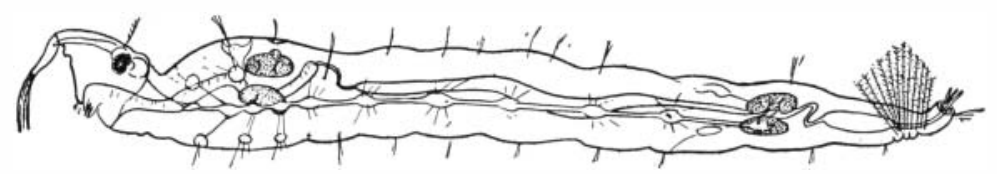

FIG. I83. The larva of the midge, Corethra. (After Weismann.)

Seasonal Range. There is no period of absence of organisms from the open water, yet the amount of life produced there varies, as it does on land, with season and temperature. In winter there are more organisms in a resting condition, and among those that continue active, there is little reproduction and much retardation of development. Life runs more slowly in the winter. Diatoms are the most abundant of the algæ at that season.

There is least plancton in the waters toward the end of winter-February and early March in our latitude. The returning sun quickens the over-wintering forms, according to their habits, into renewed activity, and up to the optimum degree of warmth, hastens reproduction and development. With the overturn of the waters in early spring comes a great rise in the production of diatoms, these reaching their maximum oftentimes in April. This is followed by a brisk development of diatom-eating rotifers and crustacea. Usually the entomostraca attain their maximum for the year in May. This rise is accompanied by a marked decline in numbers of diatoms and other algæ, due, doubtless, to consumption overtaking production. The warmth 
of summerbrings on the remaining algæ, first the greens and then the blue-greens, in regular seasonal succession. It brings with them a wave of the flagellate Ceratium, which, being much less eaten by animals than they, often gains a great ascendency, just as the browsing of grass in a pasture favors the growth of the weeds that are left untouched. Green algæ reach their maximum development in early summer, and blue-greens, in mid or late summer, when the weather is hottest.

With the cooling of the waters in autumn, reproduction of summer forms ceases and their numbers decline. The fall overturning and mixing of the waters usually brings on another wave of diatom production, followed by the long and gradual winter decline. This is often accompanied, as in the spring, by abundance of Dinobryon. The flagellate Synura (see fig. 30 on p. I03) is rather unusual in that its maximum development occurs often in winter under the ice.

The coming and going of the plancton organisms has been compared to the succession of flowers on a woodland slope; but the comparison is not a good one; for these wild flowers hold their places by continuously occupying them to the exclusion of newcomers. The planctonts come and go. They are rather to be likened to the succession of crops of annual weeds in a tilled field; crops that have to re-establish themselves every season. They may seed down the soil ere they quit it, but they may not re-occupy it without a struggle. And as the weeds constitute an unstable and shifting population, subject to many fluctuations, so also do the plancton organisms. They come and go; and while on their going we know that when they come again, another season, they will probably present collectively a like aspect, yet the species will be in different proportions. 
There are probably many factors determining this annual distribution; but chief among them would seem to be these three:

I. Chance seeding or stocking of the waters. Each species must be in the waters, else it cannot develop there; and for every species, there are many vicissitudes (such as famine, suffocation, and parasitic diseases) determining the seeding for the next crop.

2. Temperature. Many plants and animals, as we have seen, habitually leave the open waters when they grow cooler in the autumn, and reappear in them when they are sufficiently warmed in the spring. They provide in various ways (encystment, etc.) for tiding over the intervening period. Some of them appear to be attuned to definite range of temperature. Thus the Cladoceran, Diaphanosoma, as reported by Birge for Lake Mendota, has its active period when the temperature is about $20^{\circ} \mathrm{C}$. $\left(68^{\circ} \mathrm{F}\right.$.). For this and for many other entomostraca reproduction is checked in autumn by falling temperature while food is yet abundant.

3. Available Food. Given proper physical conditions, the next requisite for livelihood is proper food. For the welfare of animal planctonts it is not enough that algæ be present in the water; they must be edible algæ. The water has its weed species, as well as its good herbs. Gloiotrichia would appear to be a weed, for Birge reports that no crustacean regularly eats it, and it is probably too large for any of the smaller animals. Birge says also ('96 p.353), "I have seen Daphnias persistently rejecting Clathrocystis, while greedily collecting and devouring Aphanizomenon." Yet Strodtmann ('98) reports Chydorus sphericus as feeding extensively on Clathrocystis, even to such extent that 
its abundance in the plancton is directly related to the abundance of that alga. Each animal may have its food preference. The filaments of Lyngbya are too large for the small and immature crustaceans to handle. Ceratium has too hard a shell; it appears to be eaten only by the rather omnivorous adult Cyclops. For animal planctonts in general Anabæna and its allies and the diatoms and small flagellates appear to be the favorite food.

Obviously, the amount of food available to any species is in part determined by the numbers of other species present and eating the same things.

Plancton pulses-The organisms of the plancton come in waves of development. Now one and now another appears to be the dominant species. In most groups there are a number of forms that are competitors for place and food. The diatoms Asterionella, Fragillaria and Tabelaria may fill the upper waters of a lake together or in succession. A species of Diaptomus may dominate the waters this May, and species of Cyclops may appear in its stead next May. Yet while species fluctuate, the representation of the groups to which they belong remains fairly constant.

These sudden waves of plancton production are made possible, as every one knows, by the brief life cycle of the planctonts, and by their rapid rate of increase. If a flagellate cell, for example, divide no oftener than every three days, one cell may have more than a thousand descendants, within a month. The rotifer, Hydatina is said to have a length of life of some thirteen days, but during most of this time it is rapidly producing eggs, and the female is mature and ready to begin egg laying in 69 hours from hatching. Some of the larger animals live much longer and grow more 
slowly, but even such large forms as Daphne have an extraordinary rate of increase, as we have already indicated on pages 186 and $\mathbf{I} 87$. The rises in production grow out of:

I. Proper conditions of temperature, light, etc.

2. Abundant food

3. Rapid increase

Declines follow upon failure of any of these, and upon the attack of enemies. So swift are the changes during the growing season that those who systematically engage in the study of a lake's population take plancton samples at intervals of not more than fourteen days, and preferably, at intervals of seven days.

Local Abundance-Plancton organisms tend to be uniformly distributed in a horizontal direction. Although many of them can swim, their swimming, as we have noted in the preceding chapter, is directed far more toward maintenance of level, than toward change of location. There are, however, for many plancton organisms, well authenticated cases of irregular horizontal distribution, one of which, for Carteria, we quoted on pages I03 and I04. Alongside that record for a little flagellate, let us place Birge's ('96) record for the water-flea, Daphne pulicaria, in Mendota Lake. "The Daphnias occurred in patches of irregular extent and shape, perhaps io by 50 meters, and these patches extended in a long belt parallel to the shore. The surface waters were crowded by the Daphnias, and great numbers of perch were feeding on them. The swarm was watched for more than an hour. The water could be seen disturbed by the perch along the shore as far as the eye could reach. **** On this occasion the number was shown to be I, I 70,000 per cubic meter of water in the densest part of the swarm." 
Shoreward Range-Few plancton organisms are strictly limited to life in open water. Most of them occur also among the shore vegetation in ponds and bays and shoals. They are very small and swim but feebly, and there is room enough for their activities in any pool. They mostly belong in the warm upper strata of the lake, and similar conditions of environment prevail in any pond. It is the decp waters of the lake that maintain uniform conditions of low and stable temperature, and scanty light; and it is the organisms of the deeper strata that do not appear in the shoals.

Hence, though the aquatic seed-plants pushing out on a lake shore are stopped suddenly at given depth, as with an iron barrier, the more simple and primitive algæ of the plancton range freely into all sorts of suitable shoreward haunts. Wo shall meet with them there, commingled with numberless other forms that have not mastered the conditions of the open water. In each kind of situation (pond, river or marsh has each its plancton) we shall find a different assemblage of species. In all of them we shall find the planctonts are less transparent; in none of them will there be quite such uniformity, from place to place, as is found in the population of the open waters of the lake.

Distribution in Depth. Since plancton organisms tend to be uniformly distributed in a horizontal plane one may ply his nets at any point on a lake with the expectation of obtaining a fair sample; but not so with depth, except at times when the waters are in complete circulation. A net drawn at the surface would make a very different catch from one drawn at a depth of fifty feet. Certain species found in abundance in the one would not be represented in the other. The organisms of the lakes tend to be horizontally stratified. 
Each species has its own level; its own preferred habitat, where it finds optimum conditions of pressure, air, temperature and light. Fig. I 84 is a diagram of the midsummer distribution in depth of seven important synthetic planctonts of Cayuga Lake.

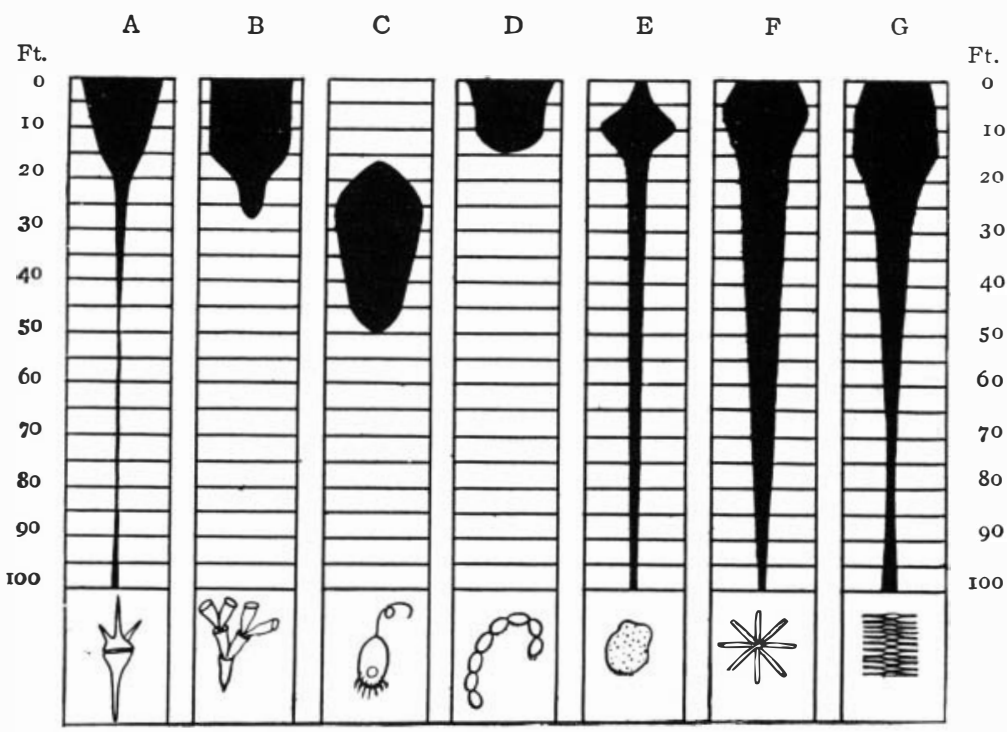

FIG. I84. Diagram illustrating midsummer distribution of seven important synthetic organisms in the first one hundred feet of depth of Cayuga Lake. $A$, Ceratium; $B$, Dinobryon; $C$, Mallomonas; $D$, Anabæna; $E$, Microcystis (Clathrocystis); $F$, Asterionella; $G$, Fragillaria.

(Based in part on Juday-15)

Light is the principal factor determining distribution in depth. This we have touched upon in Chapter II, under the subject of "Transparency." It is only in the upper strata of lakes, within the reach of effective light, that green plants can grow. Animals must likewise remain where they can find their food; whence it results that the bulk of the plancton in a lake lives in its 
uppermost part, the thickness of this productive stratum varying directly with the transparency of the water.

It is not at the surface, however, but usually a little below it - a depth of a meter, more or less - at which the greatest mass of the plancton is found. Full sunlight is perhaps too strong; for average planctonts a dilution of it is preferred. Free-swimming planctonts

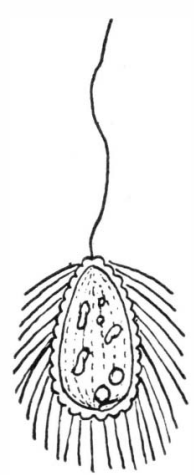

Fig. I85. Mal$10 \mathrm{mon}$ a s ploessi.

(After Kent.) such as rotifers and entomostraca move freely lipward or downward with changes of intensity of light. Anyone who has seen Daphnes in a sunlit pool congregating in the shadow of a water-lily pad will understand this. These animals rise nearer to the surface when the sun goes under a cloud, and sink again when the cloud passes. The extent of their regular diurnal migrations appears to be directly related to the transparency of the water.

Temperature also is an important factor determining vertical distribution. Forms requiring the higher temperatures are summer planctonts that live at or near the surface. Others that are attuned to lower temperatures may find a congenial summer home at a greater depth. Thus the flagellate Mallomonas (fig. I 85) in Cayuga Lake is rarely encountered in summer in the uppermost twenty feet of water, though it is common enough at depths between 30 and 40 feet, where the temperature remains low and constant. The average range of Daphne pulicaria is said to be deeper than that of other Daphnias.

The gases of the water have much to do with the distribution of animal planctonts, especially below the thermocline, where the absence of oxygen from some lakes during the summer stagnation period excludes 
practically all entomostraca. Certain hardy species of Cyclops and Chydorus appear to be least sensitive to stagnation conditions. The insect Corethra, (fig. I 83) is remarkable for its ability to live in the depths, where practically no free oxygen remains.

Age appears to be another factor in vertical distribution. On the basis of his studies of the Entomostraca of Lake Mendota, Birge ('96) has formulated for them a general law of distribution, to the effect that (I) broods of young appear first in the upper waters of the lake (quite near the surface); (2) increase of population results in extension downward, and the mass becomes most uniformly distributed at its maximum development; (3) with decline of production there is relative increase of numbers in the lower waters.

Perhaps this shifting downward merely corresponds to the wane of vigor and progressive cessation of swimming activities with advancing age.

In the case of many plants spore development or encystment may follow upon a seasonal wave of production, with a resulting change in vertical distribution. Filamentous blue-green algæ develop spores. The ordinary vegetative filaments are buoyed up in part by vacuoles within the cells, that lessen their specific gravity; but spores lack these. Hence the spore-bearing filaments settle slowly to the bottom, and may be found in numbers in the lower waters ere they have reached their winter resting place. Dinobryon maintains itself at the surface in part by means of the lashings of its flagella, but when its cells encyst, the flagella stop, and the fragmenting colonies slowly settle. Thus, both internal and external conditions have much to do with vertical distribution. In general it may be said that during their period of highest vegetative activity all plants are necessarily confined to surface waters; that most animals are closely associated with them, 
but that the constant fall of organic material toward the bottom makes it possible for some animals to dwell in the depths, if they can endure the low temperature and the other conditions found there. There are some animal planctonts, such as species of Cyclops and Diaptomus, that range the water (oxygen being present) from top to bottom. There are many that are confined during periods of activity to the warmer region above the thermocline. There are a few like Leptodora that seem to prefer intermediate depths, and there are a few (Heterocope, Limnocalanus, Mysis, etc.) that dwell in the cold water below the thermocline.

Collectively, this extraordinary assemblage of organisms that we know as plancton recalls in miniature the life of

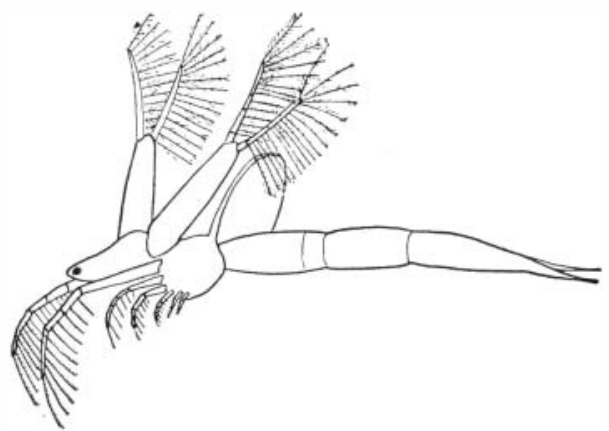

FIG. I86. Leptodora. the fields. It has, in its teeming ranks of minute chlorophyl-bearing flagellates, diatoms and other algæ, a quick-growing, ever-present food supply that, like the grasses and low herbage on the hills, is the mainstay and dependence of its animal population. It has in some of its larger algæ the counterparts of the trees that support more special foragers, are less completely devoured, and that, through death and decomposition, return directly to the water a much larger proportion of their substance. It has in its smaller herbivorous rotifers and entomostraca, the counterpart of the hordes of rodents that infest the fields. It has in its large, plant-eating Cladocerans, such as Daphne, the equivalent of the herds of hoofed animals of the plains; and 
it has at least one great carnivore, that, like the tiger, ranges the fields, selecting only the larger beasts for slaughter. This is Leptodora (fig. I 86). It is of phantom-like transparency, and though large enough to be conspicuous, only the pigment in its eye and the color of the food it has devoured are readily seen. It ranges the water with slow flappings of its great, wing-like antennæ. It can overtake and overpower such forms as Cyclops and Daphne and it eats them by squeezing out and sucking out the soft parts of the body, rejecting the hard shell. Leptodora, in a small way, functions in this society as do the fishes of the necton.

The total population of plancton in any lake is very considerable. Kofoid ('o3) reported the maximum plancton production found by himself in Flag Lake near Havana, Ill., as 667 cubic centimeters per square meter of surface: found by Ward ('95) in Lake Michigan, I76 do.; found by Juday ('97) in the shoal water of Turkey Lake in Indiana, I 439 do. Kofoid estimated the total run-off of plancton from the Illinois River as above 67,000 cubic meters per year-this the production of the river, over and above what is consumed by the organisms dwelling in it.

If we imagine the organisms of a lake to be projected downward in a layer on the bottom, this thick layer would probably represent a quantity of life equal to that produced by an average equal area of dry land.

There is hardly another ecological group of organisms that lends itself so readily to quantitative studies, since the entire fauna and flora of the plancton may be gathered by merely straining or filtering the water. All over the world, therefore, quantitative studies have been made in every sort of lake and in many sorts of streams. Extensive data have been gathered concerning the distribution and numerical abundance of the 
planctonts; but we still are sadly lacking in knowledge of the conditions that make for their abundance.

\section{II}

\section{THE NECTON}

The large free swimming animals of the fresh waters are all fishes. Indeed, as we have already noted ( $p$. 233), but a few of the fishes range through the open waters. Such are the white-fish, the ale-wife and the ciscos, - all plancton feeders, - and a few more piratical species, like the lake trout and the muskellonges that feed mainly on smaller fishes.

Necton, it will thus be seen, is not a natural society. It contains no producing class. It is sustained by the plancton and by the products of the shores.

These fishes all have a splendid development of stream-line form. They all swim superbly. And according as they feed on plancton or on other fishes they are equipped with plancton strainers or with raptorial teeth. Excellent plancton strainers are those of the lake fishes. They are composed of the close-set gill-rakers on the front of the gill arches, and they strain the water passing through. This mesh is adapted for straining the larger animal planctonts while letting the lesser chlorophyl-bearing forms slip thru. Thus the fishes reap the crop of animals that is matured, without destroying the sources for a crop to come. 


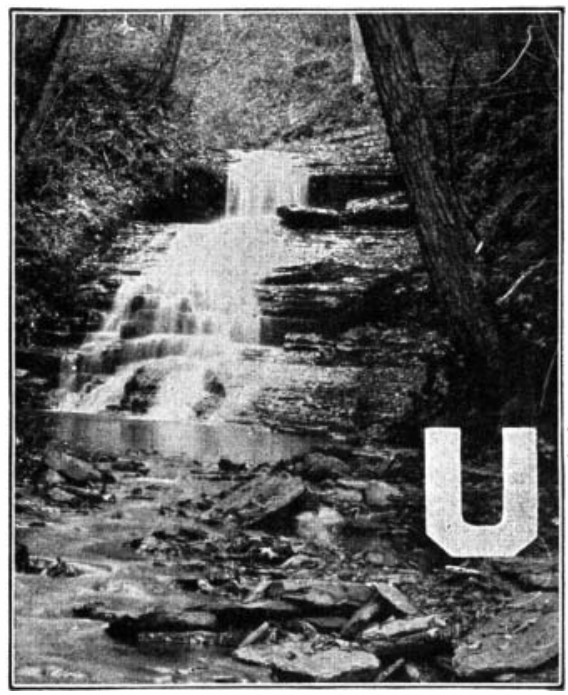

\section{$\mathbb{L} \mathbb{T} \mathbb{T} \mathbb{R} \mathbb{A}$ $S \mathbb{C} \mathbb{I} \mathbb{E} \mathbb{T} \mathbb{E S}$}

NDER the sheltering influence of shores the vascular plants may grow. Animals elude the eyes of their enemies, not by becoming transparent, but

by taking on colors and forms in resemblance to their environment. They escape capture, not alone by fleetness, but also by development of defensive armor, by shelter-building and by burrowing.

Large and small and all intermediate sizes occur together along shore, and those that appear betimes in open water make shifts innumerable for place and food and shelter for their young.

There are many factors affecting the grouping of littoral organisms into natural associations, most of them as yet but little studied; but the most important single factor is doubtless the water itself. The density of this medium and the consequent momentum of its masses when in motion so profoundly affect the form and habits of organisms that they may be roughly divided into two primary groups for which are suggested the following names: 
I. Lenitic* or still-water societies.

II. Lotic $\dagger$ or rapid-water societies, living in waves or currents.

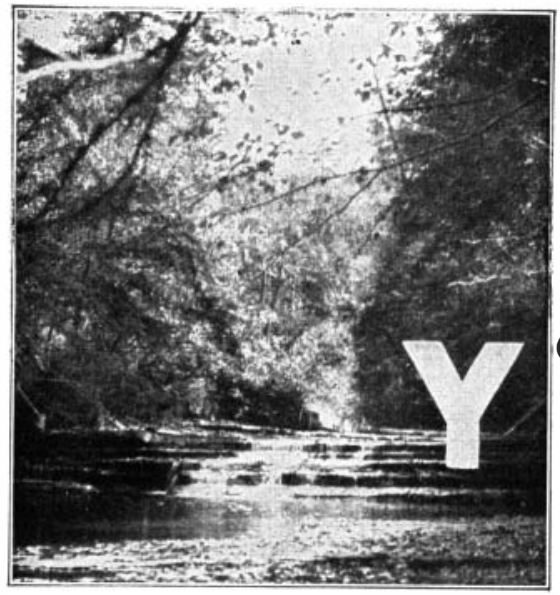

\section{$\mathbb{L} \mathbb{E} \mathbb{N} \mathbb{T} \mathbb{C}$ $S \cup \mathbb{C} \mathbb{E} \mathbb{T} \mathbb{E} S$}

OKED together, less by any common character of their own than by the lack of lotic characteristics, we include under this group name those associations of

littoral organisms that dwell in the more quiet places and show no special adaptations for withstanding the wash of waves or currents. Wherever we draw the line between lenitic and lotic regions, there will be organisms to transgress it, for hydrographic conditions intergrade. We have already seen how many organisms transgress the boundary between limnetic and littoral regions. Just as in that case we found a fairly satisfactory boundary where the increasing depth of still water is such as to preclude the growth of the higher plants, so here the boundary between lenitic and lotic regions may be placed where the movement of the water is sufficient to preclude the growth of these same plants.

*Lenis = calm, placid.

$\dagger$ Lotus $=$ washed. 
The reason why lenitic societies include practically the entire population of vascular plants has already been stated (p. I45): the plants have a complexity of organization that cannot withstand the stress of rapidly moving waters. They fringe all shoals, however, and they fill the moresheltered places with growths of extraordinary density. In such places they profoundly affect the conditions of life for other organisms: the supplies of food and light and air, and the opportunities for shelter.

Streams and still waters, inhabited by lenitic societies, may be divided roughly into three categories:

I. Those that are permanent.

2. Those that dry up occasionally.

3. Those that are only occasionally supplied with water.

These so completely intergrade, and so vary with years of abundance or scarcity of rainfall, that there is no good means of distinguishing between them. Perhaps for the humid Eastern States and for bodies of still water the words pond and pool and puddle convey a sense of their relative permanence. The population of the pond is, like that of the lake, to a large extent perennially active. It will be discussed in succeeding pages. That of the pool is composed of those forms that are adjusted to drouth: forms that can forefend themselves against the withdrawal of the water by migration, by encystment, by dessication, or by burrowing, or by sending roots down into the moisture of the bed. Some of these will be mentioned in the discussion of the population of the marshes. The puddles have a scanty population of forms that multiply rapidly and have a brief life cycle. The synthetic forms among them are mainly small flagellates and protococ- 


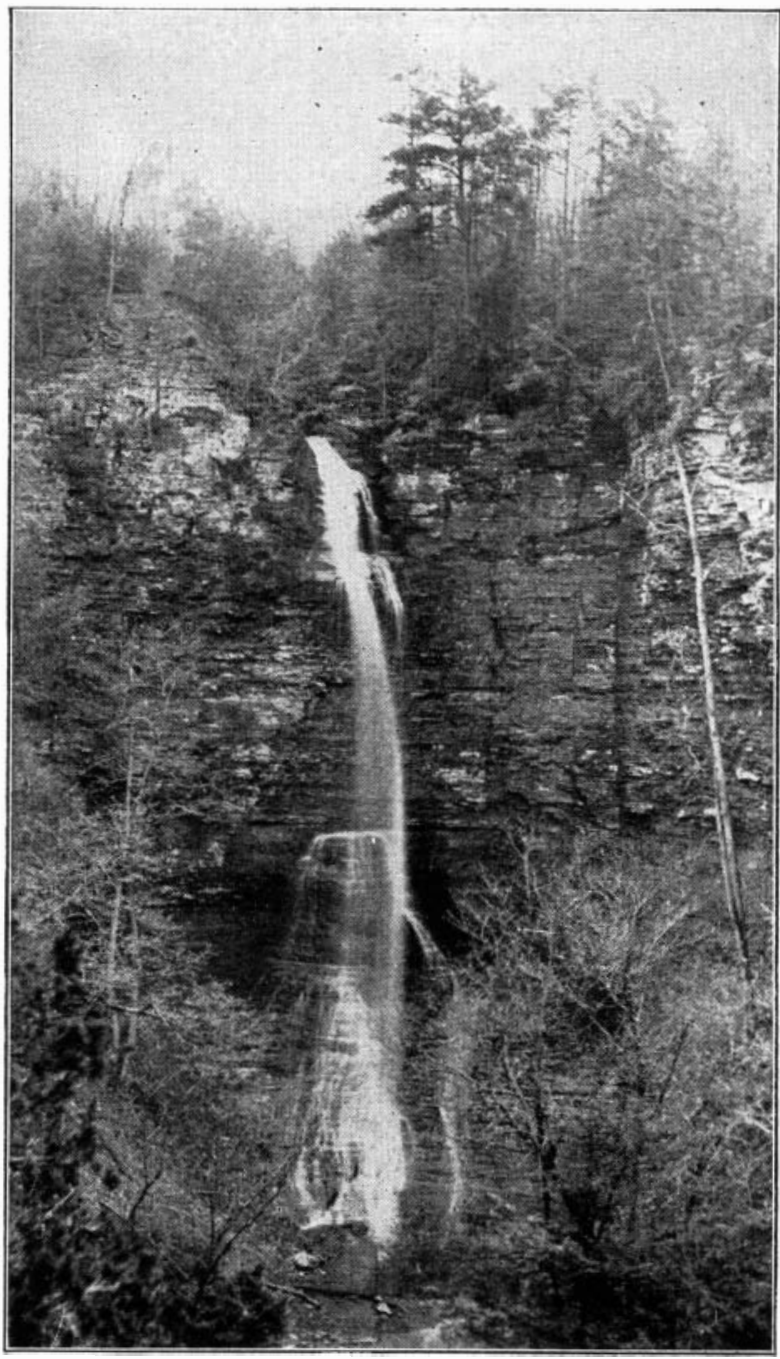

Fig. 187. Lick Brook near Ithaca in spring. Its bed runs dry later in the season. (Photo by R. Matheson.) 
coid green algæ. The herbivores are such short-lived crustaceans as Chirocephalus (see fig. 90 on p. I 84) and Apus, which have long-keeping, drouth-resisting eggs; such rotifers as Philodina, remarkable for its capacity for resumption of activity after dessication; such insects as mosquitoes. The carnivores are such adult water-bugs and beetles as may chance to fly into them.

Whether a population shall be able to maintain itself depends on the continuance of favorable conditions, at least through the period of activity of its members. In these pages we shall give attention only to the life of relatively permanent waters.

Plants-The shoreward distribution of plants in natural associations is determined mainly by two hydrographic factors: (I) movement and (2) depth of the water. It is directly related to exposure to waves and to currents. Everyone knows the difference in appearance between plants growing immersed in a quiet

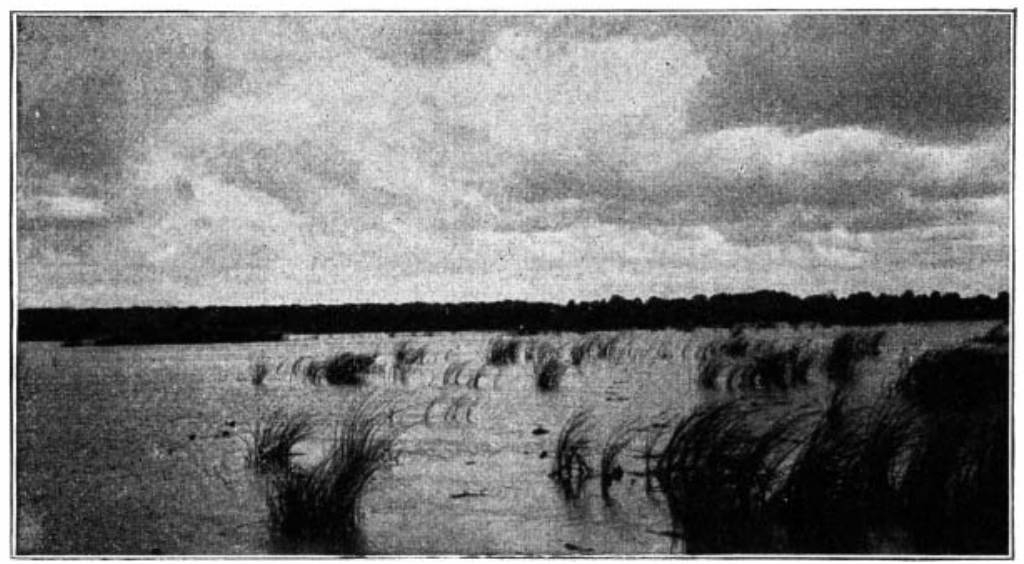

FIG. I 88. The forefront of the Canoga marshes, where partly sheltered from the waves of Cayuga Lake, clumps of the lake bulrush lead the advance of the shore vegetation. 
pool and those growing on a wave-washed shore. The former appear as if robed in filmy mantles of green, fullfledged with leaves, and luxuriant. The latter appear as if stripped for action, unbranched, slender and bare. At one extreme are the finely-branched free-floating bladderworts (see fig. I73 on p. 285) at the other are such firmly rooted, slender, naked, pliant-topped forms as the lake bulrush (figure I88) and eel-grass. These latter anchor their bodies firmly and closely to the soil, and send up into the moving waters overhead only soft and pliant vegetative parts, that offer the least possible resistance to the movement of the water, and that, if broken, are easily replaced. The long cylindric shoots of the bulrush have their vessels lodged in the axis and surrounded with a remarkable padding of air cushions. They are not easily injured. The flat ribbon-like leaves of eel-grass are marvels of adjustability to waves.

Between these two extremes are all gradations of form and of fitness. Of the pool-inhabiting type are the water crow-foot, the water milfoil, the water hornwort; of the opposite type are the long-leaved pondweeds and the pipeworts. Intermediate are the broaderleaved pondweeds and Philotria.

These sometimes are found in running streams, but they usually grow in the beds in dense mutually supporting masses that deflect the current. If one place a current meter among their tops he will find little movement of the water there.

There is another place of security from waves, for such plants as can endure the conditions there. It is on the lake's bed, below the level of surface disturbance. The stoneworts (see fig. 55 on p. I37) are branched and brittle forms, very ill adapted to wave exposure, and most of them live in pools, but a few have found this place of security beneath the waves. There are extensive beds of Chara on the bottom of our great 


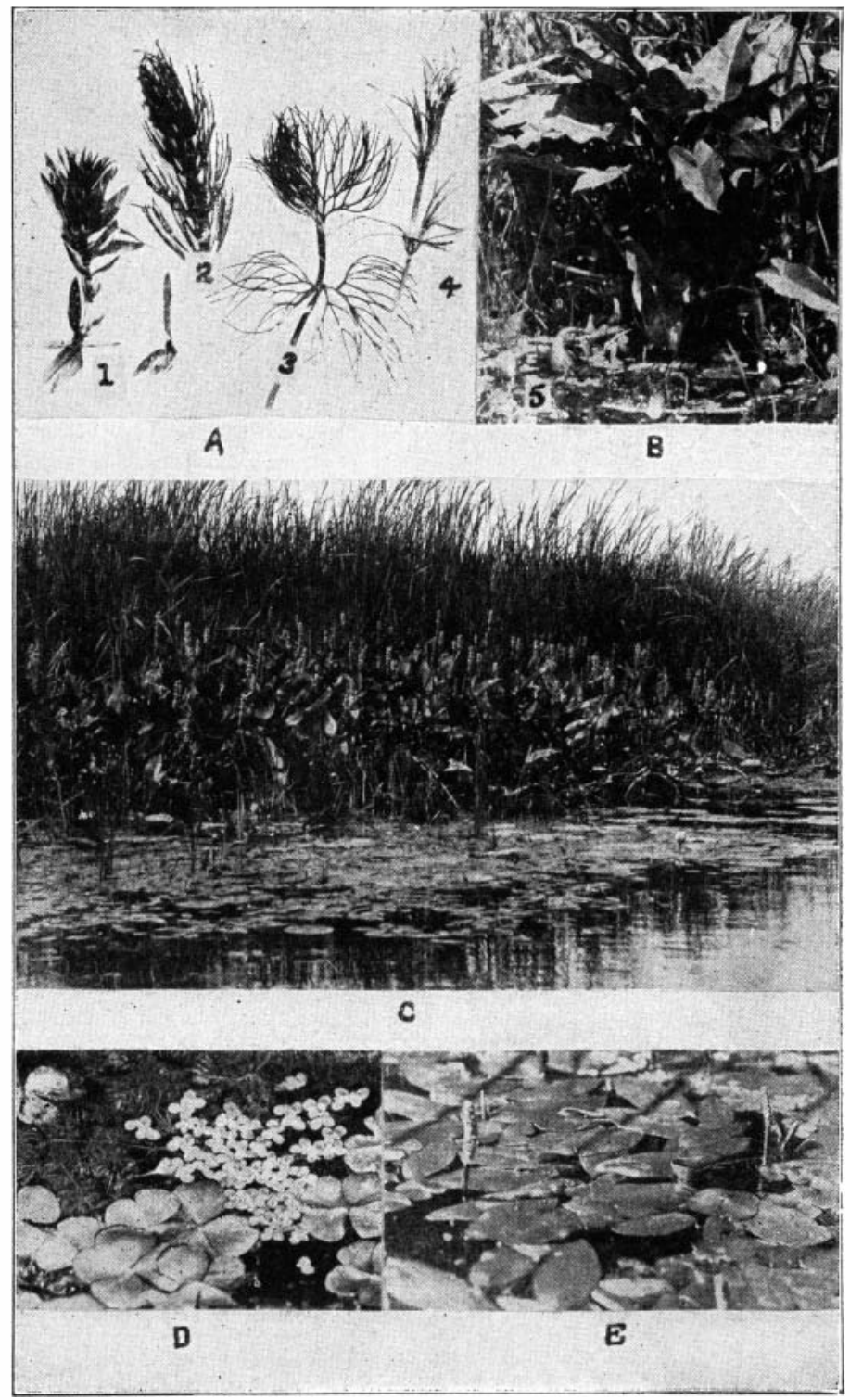

FIG. I89. Shore-line vegetation. 
lakes, at a depth of 2.5 feet more or less, and within the range of effective light. Associated with these, but usuality on the shoreward side, are beds of pondweeds. Often there are bare wave-swept shores behind these beds with no sign of aquatic vegetation that one can see from the shore.

Depth of water determines the adjustment of aquatic seed plants in three principal categories:

I. Emergent aquatics. These occupy the shallow water, standing erect in it with their tops in the air, and are most like land plants. They are by far the most numerous in species.

2. Surface aquatics. These grow in deeper water, at the front of (and oftentimes commingling with) the preceding. The larger ones, such as the water lilies are rooted in the mud of the bottom, and bear great leaves that float upon the surface. The smaller ones such as the duckweeds (see figs. 6I and 62, p. I49) are free-floating.

3. Submerged aquatics. These form the outermost belt or zone of herbage. They are most truly aquatic in habits. Except for such forms as dwell in quiet waters, they are rooted to the bottom. Depth varies considerably within this zone. It extends from the outer limits of the preceding (hardly more than five

Fig. 189.

A. Branches of four submerged water plants: (I) Philotria, (2) Ceratophyllum, (3) Ranunculus, (4) Nais.

$B$. Emergent aquatics, including a clump of arrow arum; two of the pendulous club-shaped fruit-clusters are seen at (5) dipping into the water.

$C$. Zonal arrangement of the plants of the shore-line. The background zone is cat-tail flag (Typha). Next comes a zone of pickerel-weed (Pontederia) in full flower. Next, a zone of water lilies and such other aquatics with floating leaves as are shown in $D$ and $E$. In the foreground is a zone of submerged plants-a mixture of such forms as are shown in $A$ above.

$D$. A closer view: Lemna, free-floating and Marsilia with four parted floating leaves, and Ranunculus, in tufted sprays, submerged.

$E$. The floating leaves and emergent flower spikes of a pondweed, Potamogeton. (Photo by L. S. Hawkins.) 
feet at most) to the limits of effective light. Within such a range of depth conditions of movement, pressure, warmth and light find also a considerable range; hence, the forms differ at the inner and outer margins of the zone. Its forefront is usually formed by Chara as stated above, and pondweeds follow Chara, with a number of other forms usually commingled, in the shallower part.

These groups are not free from intergradation since some forms like the spatterdock (fig. I 95 on p. 335) are in part emergent, and some of the pondweeds have a few floating leaves. But they are nevertheless convenient, and they represent real ecological differences.

Distribution of these plants in depth results in their zonal arrangement about the shore line. When all are present they are arranged in the order indicated. It is an inviolable order; for the emergent forms cut off the light from those that cannot rise above the surface, and the latter overshadow those that are submerged. The zones may vary in width and in their component species, but when all are present and crowded for room they can occur only in this order. The two accompanying figures illustrate zonal arrangement; figure $\mathrm{I} 89 \mathrm{C}$, on a low and marshy shore; figure I90, on a more elevated shore, backed by a terrestrial flora.

The alga of littoral societies are those of the plancton (practically all of which drift into the shoals) plus numberless additional non-limnetic forms, many of which are sessile. As with the vascular plants, algæ that are fragile (see fig. I98 on p. 338) and the larger that float free (Spirogyra, etc.) develop mainly in pools and quiet waters, while those having great pliancy of body (Cladophora, see fig. 46 on p. I25) and protective covering (slime-coat diatoms, etc.) are more exposed to moving waters. 


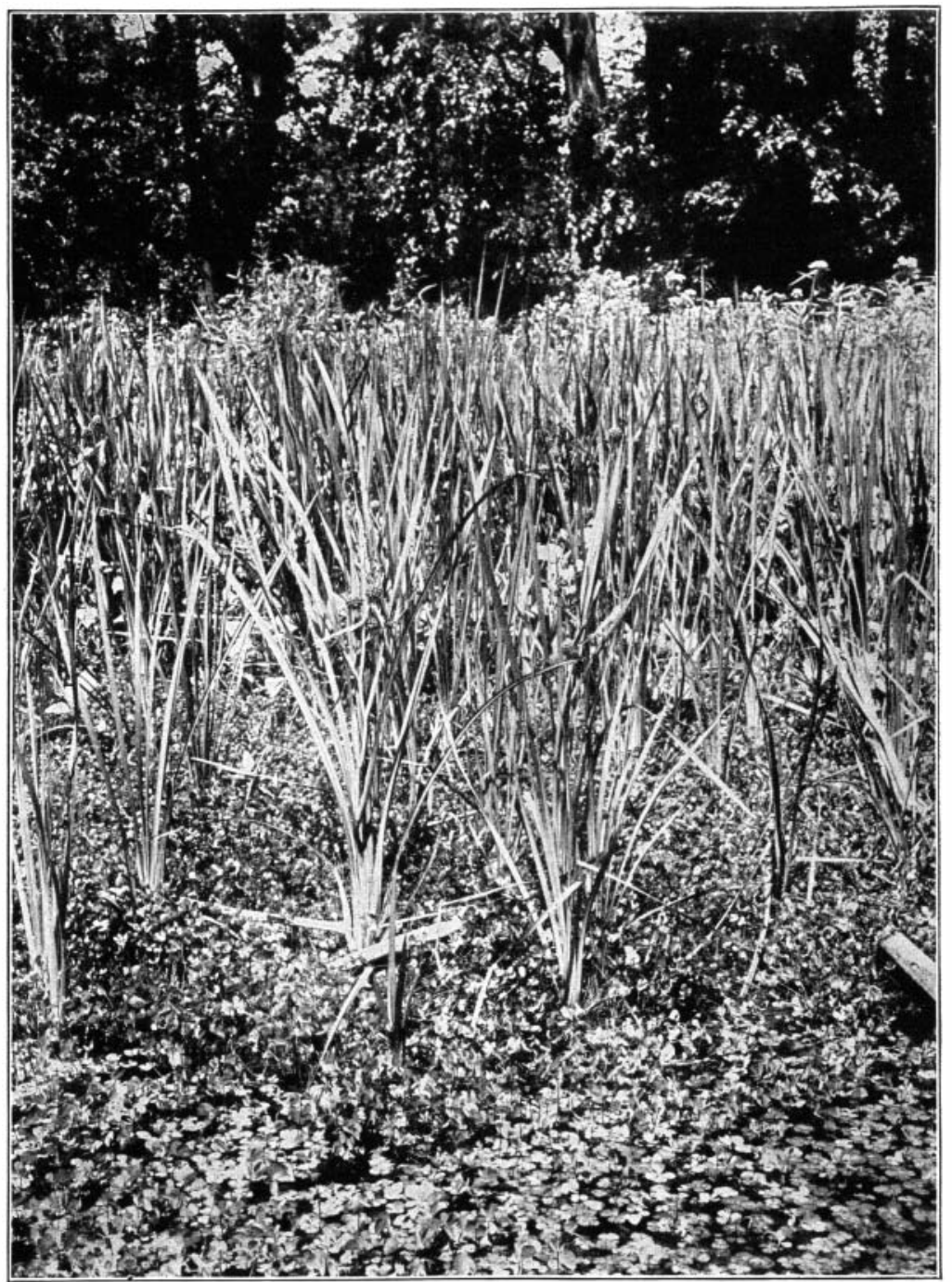

FIG. I90. Zonal arrangement of plants. At the front is a zone of Marsilea extending down into the water. Next is a zone of bur-reed, with the spiny seed-heads showing near the center of the picture. Back of this is a zone of tall composites. The flower clusters of the joe-pye-weed show above the bur-reed tops. In the background is a zone of trees. 
The animal population of the shores is likewise distributed largely in relation to water movement, or to conditions resulting therefrom. There is a zonal arrangement of animal life along shores that is only a little less definite than that of plants. It is much less obvious, for plants are fixed in position and come out more into the open and into view. Nevertheless, even the most free-roving animals, the fishes, as we have already seen (p. 233), keep in the main to certain shore-

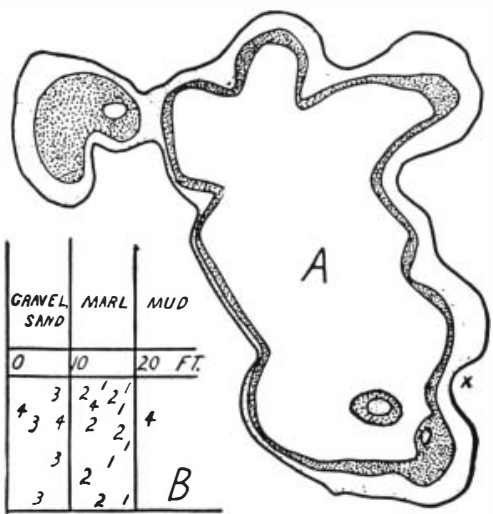

FIG. I9I. Diagram of distribution of mussels in Winona Lake, Indiana

$A$, outline of lake with the mussel zone stippled and marked out by two ten-foot contours.

$B$, shows the relation of four of the commonest species to depth and character of bottom:

I. Anodonta edentula. 3. Unio rubigniosa.

2. Anodonta grandis. 4. Lampsilis luteolus.

ward limits.

Distribution in relation to depth and to character of bottom comes out clearly in Headlee's studies of the mussels of Winona Lake. In that lake the play of the waves on shore yields a clean beach line of sand and gravel, and sifts the finer materials into deeper water. The succession is gravel and sand, marly isand, sandy marl, coarse white marl, marly mud and very soft black mud. The last named, beginning at a depth of some 20 feet, covers a very large central portion of the lake bottom. Mussels cannot live in it for they sink too deeply and the fine sediment clogs their gills. Hence the mussels are restricted to the strip along shore. Within this strip they are arranged according to hardness of bottom and exposure to waves. The accompanying diagram illustrates the distribution of four of the common species. The two Anodontas, having 
lighter shells less prone to sink, live in the deeper zone of mixed marl and mud, and so are able to forage farther out on the bottom. On account of their thinner shells they are excluded from residence near the shore line, where the waves would crush them. The heavier shelled Unio requires a more solid bottom for its support, and is uninjured by the beating of heavy waves. Hence, its shoreward distribution. Lampsilis, however, is a more freely ranging form, having a rather light shell. It overspreads the range of all the others, coming in the less exposed places rather close to shore.

Plancton animals-The animals of the shoreward plancton are less transparent than those of the lake. They are also far more numerous. They show more color. The color is often related to situation. In small ponds and marshes they are darker as a rule than in large ponds. They include forms of very diverse habits among which are the following:

I. Forms that swim freely and continuously in the more open places. These only are common to both littoral and limnetic regions.

2. Forms that are free swimming, but that rest betimes on plants; Cladocerans with adherent "neck organs"; Copepods with hooked antennæ, etc.

3. Forms that can and that do swim betimes, but that more habitually creep on plants; many ostracods, copepods and rotifers.

4. Forms that live on or burrow in the slime that covers stems or other solid supports, and that swim but poorly and but rarely in the open water; Leeches and oligochete worms, rhizopods and midge larvæ.

5. Sessile forms that cannot swim, but that become detached and drift about passively in the open water, at certain seasons; hydras, statoblasts of fresh-water sponges and of bryozoans, resting eggs of rotifers and of cladocerans, etc. 
Few of these can thrive in the waters of the limnetic region of a lake; but there is at least one member of the first group that takes advantage of an abundant supply of food in lake waters, migrates out, and develops enormously, overshadowing in numbers sometimes the truly limnetic forms. It is Chydorus sphericus. It is rather a littoral than a limnetic species, yet it often abounds in the open lakes, following a rich development there of blue-green algæ suitable for its food.

\section{SPATIAL RELATIONS}

A large part of the animal life of the littoral region is disposed in relation to upper and lower surfaces of the water. This grouping by levels is due to gravity. Where the air rests upon the water, making available an unlimited supply of oxygen, there at the surface are aggregated forms that require free air for breathing. Where the water rests upon the solid earth, there at the bottom are the forms that hide or burrow in the ground.

Plants and animals differ most markedly here. Light is the prime requisite and source of energy for chlorophyl-bearing plants. It is not light but oxygen that holds many animals at the surface of the water; and it is indifference to light that allows many other animals to dwell in the obscurity of the bottom.

Life on the bottom has a number of advantages among which are the following:

I. Shelter is available.

2. Energy is saved when a resting place is found, and continuous swimming is unnecessary.

3. Gravity brings food down from above.

4. Hiding from enemies is easier in absence of strong light.

It has also its perils chief among which are:

$\left.\begin{array}{l}\text { I. Failure of oxygen } \\ \text { 2. Excess of silt }\end{array}\right\} \begin{gathered}\text { either of which may result } \\ \text { in suffocation. }\end{gathered}$ 
In the last chapter we have discussed the more important lines of specialization that have fitted the members of the bottom population to meet or to profit by these conditions. Under the subject "pond societies," further specific illustrations will be cited.

Life at the surface is less tranquil than on the bottom. There are two kinds of animals that can maintain themselves there. (I) Those having bodies (together with the air they hold about them) lighter than the water; which rise to the surface like a cork and have to swim in order to go down below. These are mainly adult insects whose problem of getting air we have discussed in the preceding chapter.

(2) Those having bodies heavier than the water, which maintain themselves at the surface by some sort of hold on the surface film. If free-swimming, they have to swim up to the surface and break through the film before they can use it for support. Certain insect larvæ, water-fleas, rotifers, ciliates, etc., are of this habit. Creeping forms must first climb up some emergent stem, break through and then glide away suspended underneath the film. Pond-snails and hydras are of this sort. In an aquarium one may see either, hanging suspended, and dimpling the surface where the foot is attached by the downward pull on the film.

The relations of certain water-fleas to the surface film are particularly interesting. For many of these, such for example as Bosmina, this is a constant source of peril. If in swimming a Bosmina accidentally breaks through this film it falls over on its side and is held there helpless lying on the surface unable to swim away. Unless some disturbance dash it again beneath the water, its only chance for release seems to lie in moulting its skin and slipping out of it into the water. Usually when a catch of surface plancton from 
Cayuga is placed in a beaker, the Bosminas begin to break through one by one, and soon are gathered in a little floating company in the center.

Scapholeberis (fig. I92), however, appears to be especially fitted to take advantage of the surface film. It is able to maintain a proper position at the surface: it possesses specialized bristles for breaking the film and laying hold upon it; its ventral (uppermost) margin is straightened and extended posteriorly in a long spine; as much contact may be had as is needed. Suspended beneath the surface, where algæ from below and pollen from the air accumulate, Scapholeberis

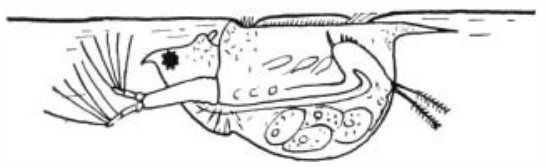

FIG. 192. Scapholeberis mucronata, suspended beneath the surface film. (After Scourfield.)

rows placidly about, foraging; or it is borne along by the towing of air currents acting on the surface water-a sort of submarine sailing.

Scapholeberis is unique among water-fleas in this habit. There is also an Ostracod, Notodromas, of similar habit; and it is worthy of note that both these creatures have blackish markings on the ventral edges of the valves and are pale dorsally. As in the sloths which climb inverted in trees, the usual coloration of the body is reversed with reversal of position.

Then there are some little creatures that take advantage of the tenacity of the surface film to cover themselves with it as with a veil. Copepods, ostracods, rotifers and what not, climb up the surface of emergent stems, pushing a film of water ahead until they are well above the general surface level, where they rest and 
feed, and find more oxygen. The larva of Dixa is one
of the most interesting of these. It will float in the
surface film, but not for long, if any support be at hand.
Touching a leaf it immediately bends dcuble, and
pushes forward by alternate thrusts at both ends, until

feed, and find more oxygen. The larva of Dixa is one
of the most interesting of these. It will float in the
surface film, but not for long, if any support be at hand.
Touching a leaf it immediately bends dcuble, and
pushes forward by alternate thrusts at both ends, until

feed, and find more oxygen. The larva of Dixa is one
of the most interesting of these. It will float in the
surface film, but not for long, if any support be at hand.
Touching a leaf it immediately bends dcuble, and
pushes forward by alternate thrusts at both ends, until

feed, and find more oxygen. The larva of Dixa is one
of the most interesting of these. It will float in the
surface film, but not for long, if any support be at hand.
Touching a leaf it immediately bends dcuble, and
pushes forward by alternate thrusts at both ends, until

feed, and find more oxygen. The larva of Dixa is one
of the most interesting of these. It will float in the
surface film, but not for long, if any support be at hand.
Touching a leaf it immediately bends dcuble, and
pushes forward by alternate thrusts at both ends, until it has lifted a film of water to a satisfactory level.

On the surface are deposited the eggs of many insects having aquatic larvæ, but these eggs are heavier than

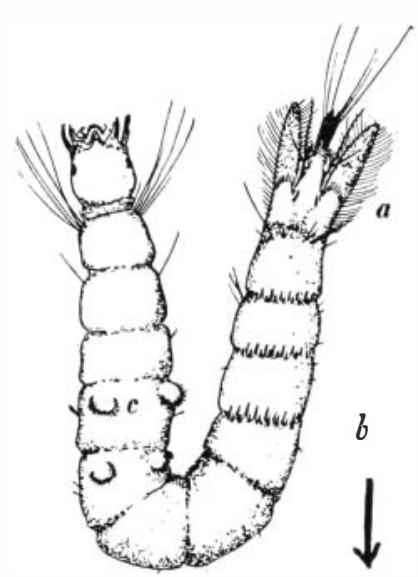

FIg. I93. Larva of a Dixa midge, inverted, to show: $a$, caudal lobe; $b$, creeping bristles; $c$, prolegs. The arrow indicates the direction of locomotion, middle foremost, both ends trailing.

tip of the abdomen. carrying them securely in After a long preparatory flight, consisting of coursing back and forth in nearly horizontal lines at shoulder height above the surface of the water-a performance that lasts often twenty minutes-she settles down on the surface and rests there with outspread feet. The usefulness of her elongate tarsi is

water, and unless anchored to some solid support or buoyed up with floats (as are such eggs as those of Culex and Corethra) nearly all of them settle to the bottom. There are, however, a few midges whose egg-clusters float freely. A brief account of the egg-laying of one of them, Chironomus meridionalis, will illustrate several points of dependence on the surface tension.

The female midge, when ready to lay her eggs, rests for a time on some vertical stem by the water side in the attitude illustrated in figure I94. She extrudes her eggs which hang suspended at the She then flies over the water in a rounded clump of gelatin. put has lifted a film of water to a satisfactory level. 
here apparent. They rest like long out-riggers radiately arranged upon the surface, easily supporting her weight while she liberates the egg mass and lets it down into the water. At the top of the egg clump appears a circular transparent disc from which the egg mass depends. This disc catches upon the surface film, tho pulled down into it in a little rounded pit-like depression

the eggs descend pulling out the gelatin
attaching them to the disc into a slender
thread that thus becomes stretched to
a length of several inches. The female
flies away to the shore and leaves them
so. Then they drift about like floating
mines, transported by breezes and cur-
rents. This little disc of gelatin dimp-
ling the surface film is indeed a frail

FIG. 194. The egg-laying of Chironomus meridionalis.

$A$, The female at rest extruding the egg-mass.

$B$, The female resting on the surface film, letting the egg mass down into the water.

$C$ and $D$, The egg mass liberated and hanging suspended from the surface film by a delicate gelatinous cord attached to a small disc-like float.

bark for their transportation. When driven by waves and currents, they break their slender moorings and settle to the bottom, or adhere to floating stems against which they are tossed.

There is another phenomenon of the water surface so curious and interesting it merits passing mention here. There is a black wasp Priocnemis flavicornis, occasionally seen on Fall Creek at the Cornell Biological Field 
Station, that combines flying with water transportation. Beavers swim with boughs for their dam, and waterstriders run across the surface carrying their booty, but here is a wasp that flies above the surface towing a load too heavy to be carried. The freight is the body of a huge black spider several times as large as the body of the wasp. It is captured by the wasp in a waterside hunting expedition, paralyzed by a sting adroitly placed, and is to be used for provisioning her nest. It could scarcely be dragged across the ground, clothed as that is with the dense vegetation of the waterside; but the placid stream is an open highway. Out onto the surface the wasp drags the huge limp black carcass of the spider and, mounting into the air with her engines going and her wings steadily buzzing, she sails away across the water, trailing the spider and leaving a wake that is a miniature of that of a passing steamer. She sails a direct and unerring course to the vicinity of her burrow in the bank and brings her cargo ashore at some nearby landing. She hauls it upon the bank and then runs to her hole to see that all is ready. Then she drags the spider up the bank and into her burrow, having saved much time and energy by making use of the open waterway.

Intermediate between surface and bottom the life of the water that is not included in either of the two strata we have just been discussing, but that has continuous free range of the open water, is still considerable. It corresponds in part to the plancton of the open waters, as we have seen. It corresponds in part, also, to the necton; and, as in the open water, so also in the shoals, the larger and more important free-swimming animals are fishes. Its spatial relations are complicated by the habit some air-breathing forms (especially insects) have of ranging downward freely thro the depths; 
also by the way in which forms like Chironomus, that ordinarily remain in hiding in the bottom, come out betimes in the open and take a swim. But there yet remain at least two classes of organisms that belong neither to the top nor to the bottom, nor yet to the free-swimming population. These are forms that are able to sustain themselves above the mud by taking advantage of plant stems or other solid supports. These get their oxygen from the water. They are:

I. Climbing forms, that hold on by means of claws, as do the scuds and some dragonfly, damselfly and mayfly larvæ, or by a broad adhesive foot as do certain minute mussels. Many members of this group find temporary shelter between the leaves and scales of plants.

2. Sessile forms that remain more or less permanently attached, like sponges, bryozoans, hydras, etc.

Many members of both these groups construct for themselves shelters. Chironomus, for example, while usually living in such tubes as are shown in figure I 34 on page 226, is able to creep about freely upon the stem. Cothurnia (fig. 73) and Stentor, and many sessile rotifers build themselves shelters.

Such support may be found on the bottom itself where that is hard; but the bottom is soft where most seed-plants grow. Furthermore, to ascend and remain above the level of the hordes of voracious bottom dwellers must be a means of safety. It is clear, therefore, that plants rising from the bottom and branching extensively must add enormously to the biological richness of the shoals, by the support and shelter they afford to such animals as these.

Size-As on land a weed patch is a miniature jungle, having a population of little insects roughly correspond- 
ing in social functions to the larger beasts of the forest, so in the water there are large and small, assembled in parallel associations. The larger, as a rule, inhabit the more open places. Paddle-fish and sturgeons and gars belong to the rivers; the quantative demands of their appetites exclude them from living in the brooks There is not a living there for them. Little fishes belong to the brooks and to the shoals. In our diagram on page 233 we have already shown how in a small lake shoreward distribution of the fishes corresponds roughly with their size, the largest ranging farthest out, and the smallest sticking most closely to shelter. The senior author has shown (07) a parallel to this in the distribution of diving beetles in an angle of the shore of a weedy pond. Here the most venturesome beetle was Dytiscus (see fig. I29 on p. 22I). It was taken at the front of the cat-tails in about three feet of water. The associated species were disposed closely, tho not strictly in accordance with their size, between that outer fringe and the shore, Acilius, Coptotomus, Laccophillus, Hydroporus, (see fig. I30) Colambus and Bidessus following in succession, the last named (a mere molecule of a beetle, having but $\frac{1}{26 \sigma}$ the weight of Dytiscus) being found only among the trash at the very shore line.

\section{LIFE IN SOME TYPICAL LENITIC SITUATIONS}

The association of organisms in natural societies is controlled by conditions; but conditions intergrade. Lakes, ponds, rivers, marshes all merge insensibly, each into any of the others; and their inhabitants commingle on their boundaries. Yet these names stand for certain general average conditions that we meet and recognize, and with which certain organisms are regularly associated. It will be worth while for us to note the main characteristics of the life of several of the more typical of such situations. 
Pond societies - The kind of associations we now come to discuss are typically represented in ponds, but they occur also in any bodies of standing fresh water, that are not too deep for growth of bottom herbage, nor too exposed to wind and wave for the growth of emergent

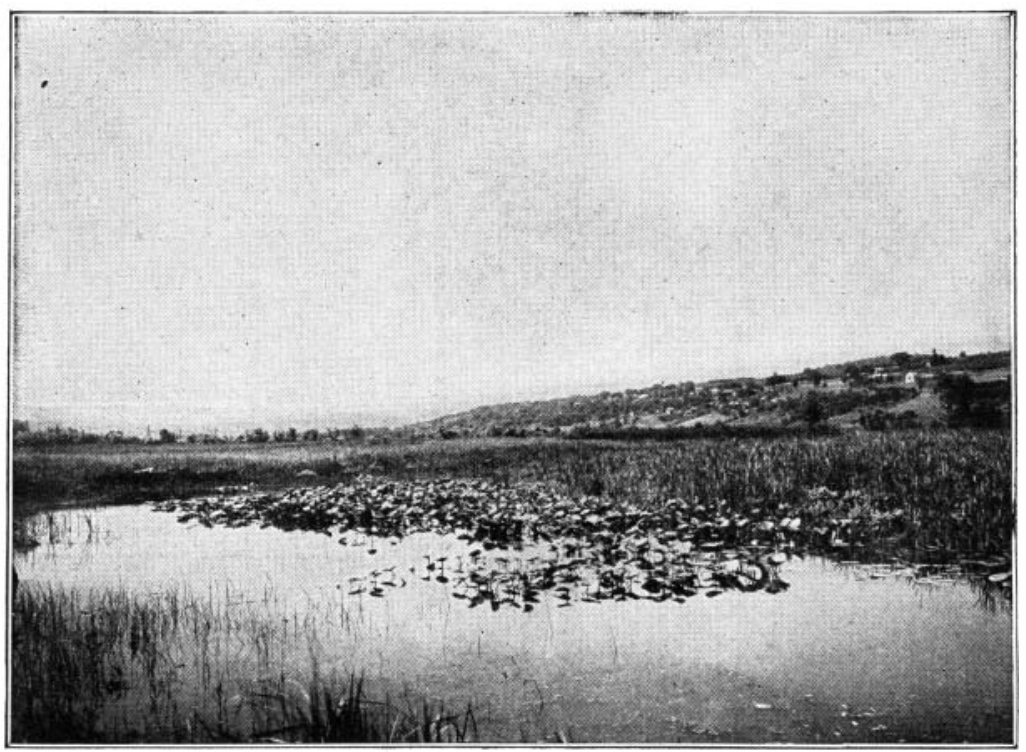

FIG. 195. Where marsh and pond meet. The head of "the cove" at the Cornell Biological Field Station. Beds of spatterdock backed by acres of cattail flag. Neguena valley in the distance.

aquatics along shore. The same forms will be found in ponds, lagoons, bayous, sheltered bays and basinlike expansions of streams. The bordering aquatics will tend to be arranged in zones, as discussed in the preceding pages, according to the closeness of their crowding.

I. The shoreward zone of emergent aquatics will include, in our latitude, species of cat-tail (Typha), of 
bur-reed (Sparganium), of bulrush (Scirpus), of spikerush (Eleocharis), of water plantain (Alisma), of arrowhead (Sagittaria), and arrow-arum (Peltandra), of pickerel-weed (Pontederia), of manna grass (Glyceria), etc.

2. The intermediate zone of surface aquatics will include such as:

(a). These rooted aquatics with floating leaves: white water-lily (Castalia), spatterdock (Nymphæa), water shield (Brasenia), pondweed (Potomogeton), etc.

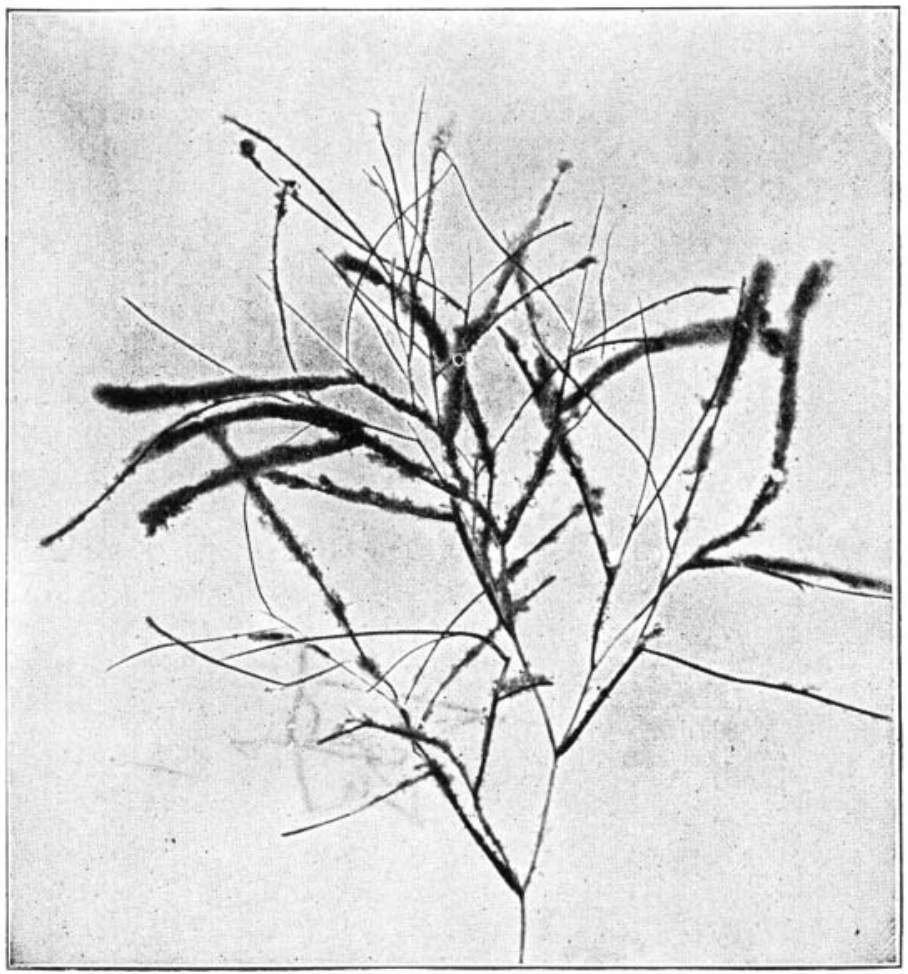

Fic. 196. A spray of the sago pondweed, Potamogeton, coated with slime-coat diatoms, its leaf tips bearing dwelling tubes of midge larvæ (Chironomus). 
(b). These free-floating aquatics; species of duckweed (Lemna, Spirodela), water fernworts (Azolla, Salvinia), liverworts (Riccia), etc.

3. An outer zone of submerged plants will include such forms as pondweeds (Potamogeton), hornwort (Ceratophyllum), crow-foot (Ranunculus), naiad (Najas), eel-grass (Zostera), stonewort (Chara), etc.

These grow lustily and produce great quantities of aquatic stuff which serves in part while living, but probably in a larger part when dead, for food of the animal population, and the ultimate residue of which slowly fills up the pond. These plants contribute largely to the richness and variety of the life in the pond, by offering solid support to hosts of sessile organisms, both plants and animals. Their stems are generally quite encased with sessile and slime-coat algæ, rotifers, bryozoans, sponges, egg masses of snails and insects and dwelling tubes of midges (fig. I96). Especially do floating leaves seem to attract a great many insects to lay their eggs on the under surface. This is doubtless a shaded and cleanly place, so elevated as to be favorable for the distribution of the young on hatching.

The alge of ponds are various beyond all enumerating. It is they, rather than the more conspicuous seed-plants, that furnish the basic supply of fresh food for the animal population. Small as they are individually, their rapid rate of increase permits mass accumulation which often become evident enough. Such are:

(I). The masses of filamentous algæ, (Spirogyra and its allies; Ulothrix, Conferva, etc.) collectively called "blanket algæ" that lie half-floating in the water, or are buoyed to the surface by accumulated oxygen bubbles.

(2). The beautiful fringes of branching sessile algæ (Chætophora, fig. I98, Cladophora, etc.) that envelop every submerged stem as with a drapery of green. 
(3). The lumps of brownish gelatin inclosing compound colonies (Rivularia, see fig. $5^{2}$ on p. I34, etc.), that are likely to cover the same stems later in the season, and that sometimes seem to smother the green vegetation.

(4). The spherical lumps of greenish gelatin that lie sprinkled about over the bottom-rather hard lumps inclosing compact masses of filaments of Nostoc, etc.

(5). The accumulated freeswimming forms that are not seen as discrete masses, but that tint the water. Volvox tints it a bright green; Dinobryon, yellowish; Trachelomonas, brownish; Ceratium, grayish, etc.

Such differences as these in superficial aspect, coming, as many of them do, with the regularity of the seasons, suggest to one who has studied them the principal component of the masses; but one must see them with the microscope for certain determination.

The animals of the pond that breathe free air are a few amphibians (frogs and salamanders), a few snails (pulmonates) and many insects. The insects fall into four categories according to their more habitual positions while taking air:

(I). Those that run or jump upon the surface. Here belong the water-striders and their allies-long legged insects equipped with fringed and water-repellent feet that take hold on the surface film, but do not break through it. Here belong many little Diptera that rest down upon the surface between periods of flying. 
Here belong the hosts of minute spring-tails that gather in the edges in sheltered places, often in such numbers as to blacken the surface as with deposits of soot. Minute as these are they are readily recognized by their habits of making relatively enormous leaps from place to place.

(2). Those that lie prone upon the surface. Best known of these because everywhere conspicuous on still

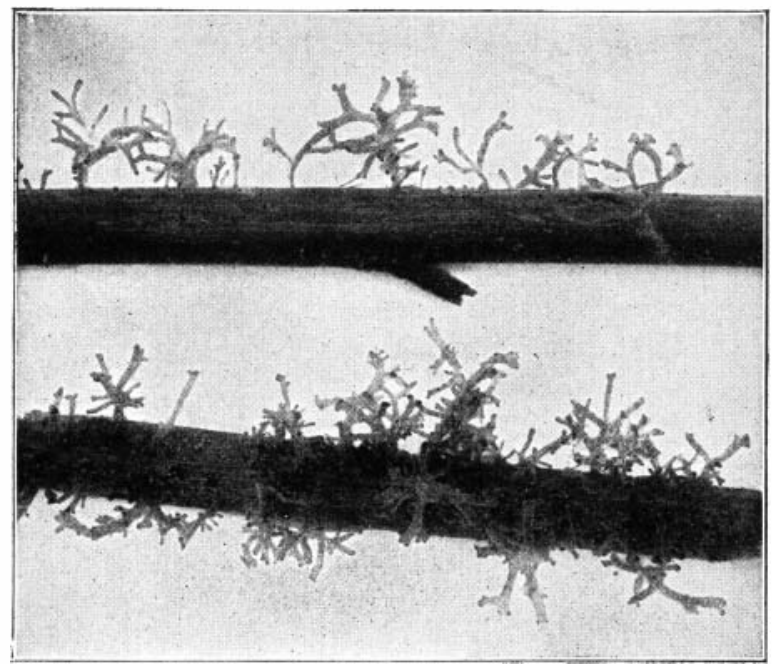

FIG. 198. Two fallen stems enveloped with a rich growth of the alga, Chatophora incrassata.

waters, are the whirl-i-gig beetles. Less common and much less conspicuous are the pupæ of the soldier-flies (Stratiomyia, etc.) and the larvæ of the Dixa midges.

(3). Those that hang as if suspended at the surface, with only that part of the body that has to do with intake of air breaking through the surface film. Here belong by far the larger number of aquatic insects. Here are the bugs and the adult beetles, alertly poised, 
with oar-like hind legs swung forward, ready, so that a stroke will carry them down below in case of approach of danger. Here hang the wrigglers-larvæ and pupæ of mosquitoes. Here belong the more passive larvæ of many beetles and flies and the pupæ of swale-flies and certain crane-flies.

(4). Those that rest down below, equipped with a long respiratory tube for reaching up to the surface for

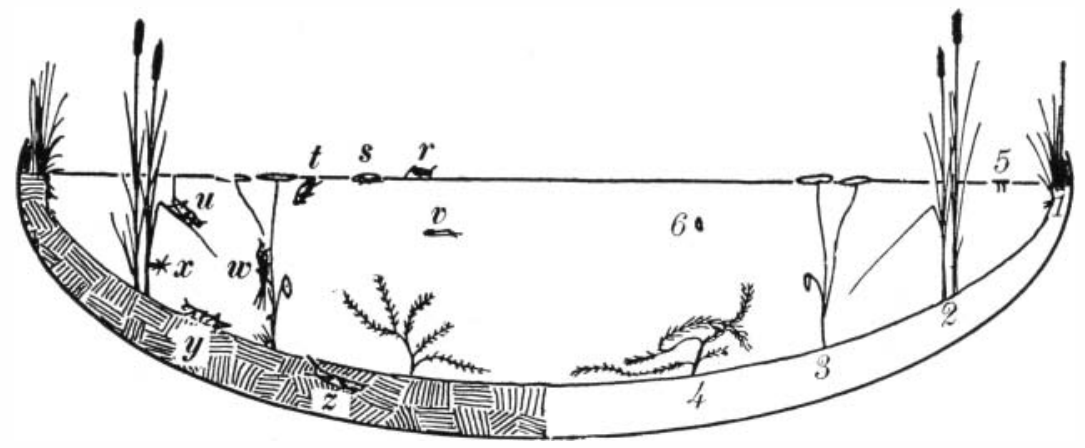

FIg. I99. Diagram of distribution of pond life. The right side illustrates the zonal distribution of the higher plants. $I$, shore zone; 2, standing emergent aquatics; . 3, aquatics with floating leaves; 4, submerged aquatics; 5 , floating aquatics; 6 , free swimming algæ of the open water.

The left side represents the principal features of the distribution of animals. $\quad r, s, t, u$, forms that breathe air; $v, w, x, y$, and $z$, forms that get their oxygen from the water.

(From the Senior Author's General Biology)

air. Such are Ranatra, and the rat-tailed maggots of syrphus-flies.

The animals of the pond that are more strictly aquatic in respiratory habits (being able to take their oxygen supply from the water itself) are so numerous that we shall be able to mention only a few of the larger and more characteristic forms. First there are the inhabitants of the bottom. These fall into two principal categories, the free-living and the shelter-building forms. The free-living forms may be grouped as follows: 
(I). Bottom sprawlers that lie exposed, or only covered over with adherent silt. These are character. ized by a marked resemblance to their environment. Such crustaceans as the crawfish and Asellus, such insects as Ephemerella, Cænis and other mayfly nymphs

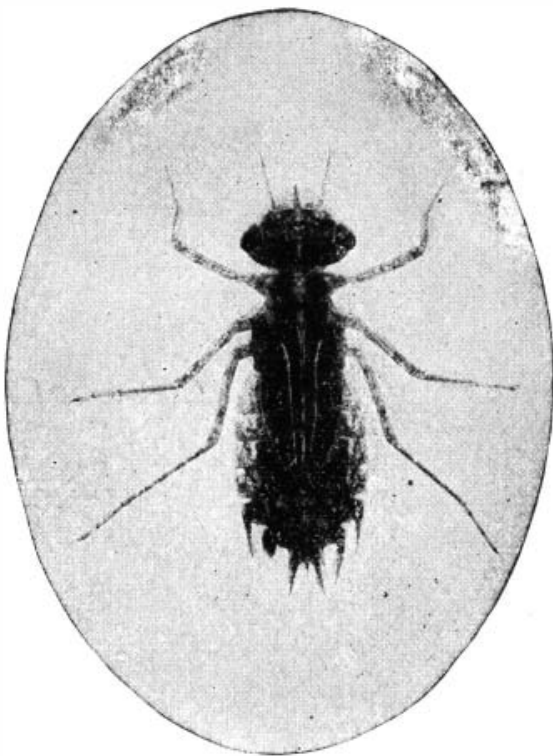

Гig. 200. A botrom sprawler: nymph of of the dragonfly, Celithemis eponina.

Libellula, Didymops, Celithemis (fig. 200) and other dragonfly nymphs, and certain snails and flatworms belong here.

(2). Bottom dwellers that descend more or less deeply into the mud or sand, by the various means already discussed in the preceding chapter. Among the shallow burrowers are many shell-bearing molluscs, both mussels and snails; a few mayfly and dragonfly nymphs. Descending more deeply in muddy beds are some true worms and horsefly larvæ.

The shelter-building forms of the bottom may be grouped as:

(I). Forms making portable shelters. These are mainly caddis-worms that construct cases of pieces of wood or grains of sand.

(2). Forms making fixed shelters. These are such caddis-worms as Polycentropus, such worms as Tubifex (see fig. 83 on p. I74) and such midges as Chironomus (see fig. I34 on p. 220). 
It is some of these animals of the pond bottom that give to the littoral region its great extension out under the open waters of the lakes. It is only a few members of the population that are able to endure conditions in the depths far out from shores. These are such as:

Small mussels of genus Pisidium.

Mayfly nymphs of the genus Hexagenia.

Midge larvæ of the genus Chironomus.

Caddis-worms in the cylindric cases of sand, not yet certainly identified, etc.

The larger animals of the pond that belong neither to surface nor bottom and that correspond to neither plancton nor necton of the open water may be grouped as:

(I). Climbing forms (most of which can swim on occasion), such as the scuds (Amphipods), the nymphs of dragonflies such as Anax, of damselflies such as Lestes and Ischnura, of mayflies such as Callibætis, larvæ of caddisflies such as Phryganea and of moths such as Paraponyx, mussels such as Calyculina, and many leeches, entomostracans and rotifers.

(2). Sessile forms such as hydras, sponges, bryzoans and rotifers.

\section{II}

Marsh Societies.-We come now to consider the associations of organisms in waters that are not toodeep for the growth of standing aquatics. Shoalness of water and instability of temperature and other physical conditions at once exclude from residence in the marsh the plants and animals of more strictly limnetic habits; but it is doubtless the presence of dense emergent plant growth that most affects the entire population. This gives shelter to a considerable number of the higher vertebrates, and these rather than the fishes are the large consumers of marsh products. The muskrat 
breeds here and builds his nest of rushes. He prefers, to be sure, the edge of a marsh opening, where in deep water he may find crawfishes and molluscs, with which to vary his ordinary diet of succulent shoots and tubers.

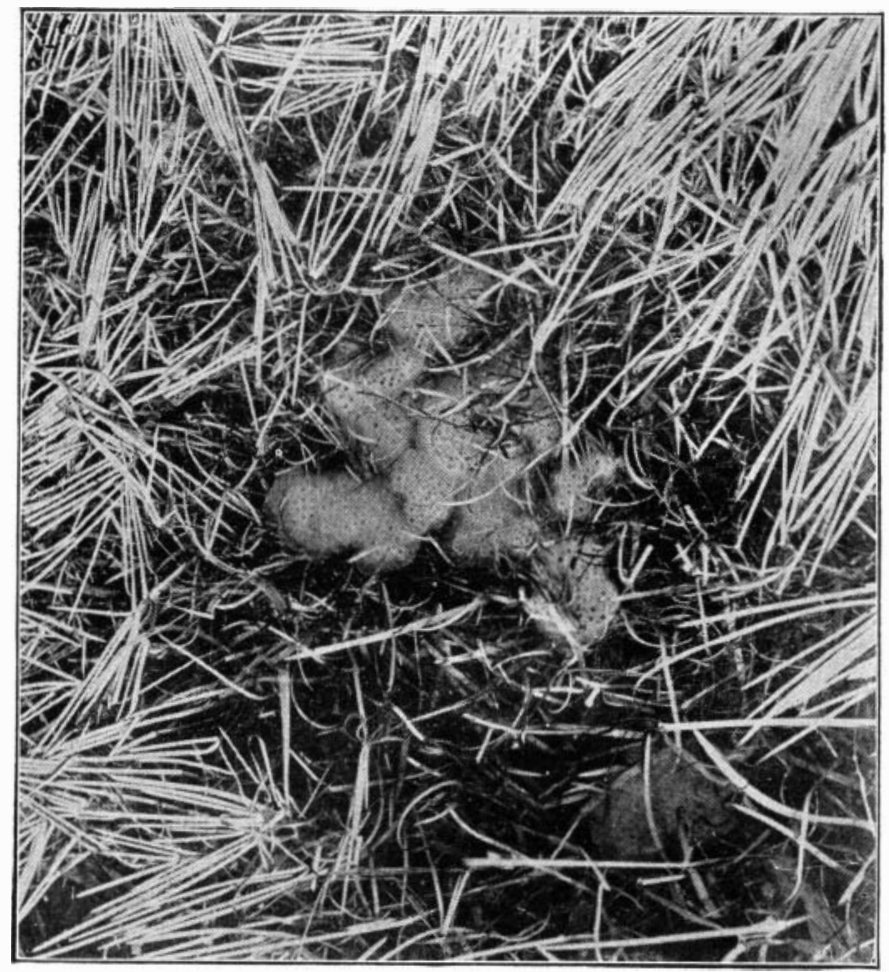

Fig. 20I. The eggs of the spotted salamander, Ambystoma punctatum.

(Photo by A. A. Allen.)

Deep in the marsh dwell water birds, such as grebes, rails, coots, terns, bitterns, and in the north, ducks and geese as well. Such non-aquatic birds as the long-billed marsh-wren and the red-winged blackbird use the top of the marsh cover as a place to build their nests and 
use also the leaves of marsh plants for building materials. Several turtles and water snakes are permanent residents as are also a few of the frogs. Most of the frogs visit the marsh pools at spawning time, making the air resound with their nuptial melodies. The spotted salamander is the earliest amphibian to spawn there. Though the adult is but a transient, its larvæ remain in the marsh pools through the season.

The plants are the same kinds found in the marginal zone of the pond border, but here they often cover large areas in a nearly pure stand. In

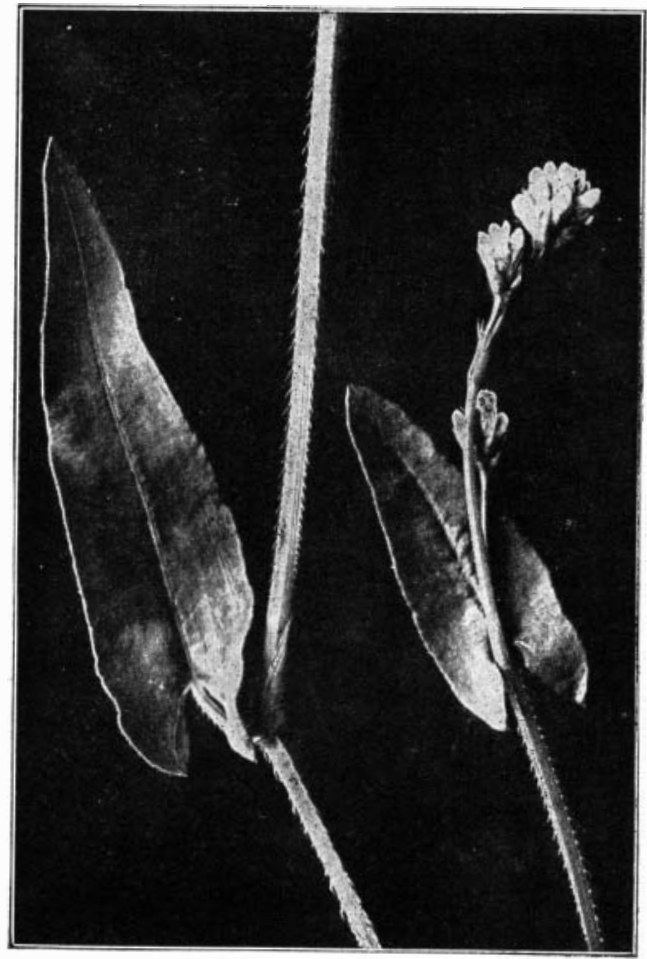

FIG. 202. Tear-thumb.

our latitude in the more permanent waters, the dominant species usually are cat-tail, phragmites, bur-reed and the soft-stemmed bulrushes; in the shoals that dry up each year they are sweet flag, sedges, manna grass and the hard-stemmed bulrushes. Such plants as these have strong interlaced roots and runners that form the basis of the marsh 
cover, and that support a considerable variety of more scattering species. One of the most widespread of these secondary forms is the beautiful marsh fern, whose black rootstocks over-run the tussocks of the sedges, shooting up numberless fronds. Scattering semi-aquatic representatives of familiar garden groups are the marsh bellwort (Campanula aparinoides), the marsh St. John's wort (Hypericum virginicum) and the marsh skull-cap (Scutellaria galericulata): these are dwarfish forms, however, that nestle about the bases of the taller clumps. With them are straggling prickly forms, such as the marsh bedstraw (Galium palustre), the white grass (Leersia) and the tear-thumb (Polygonum sagittatum, fig. 202). Strong growing forms that penetrate the marsh cover with stout almost vine-like stems are the marsh five-finger (Potentilla palustris) the

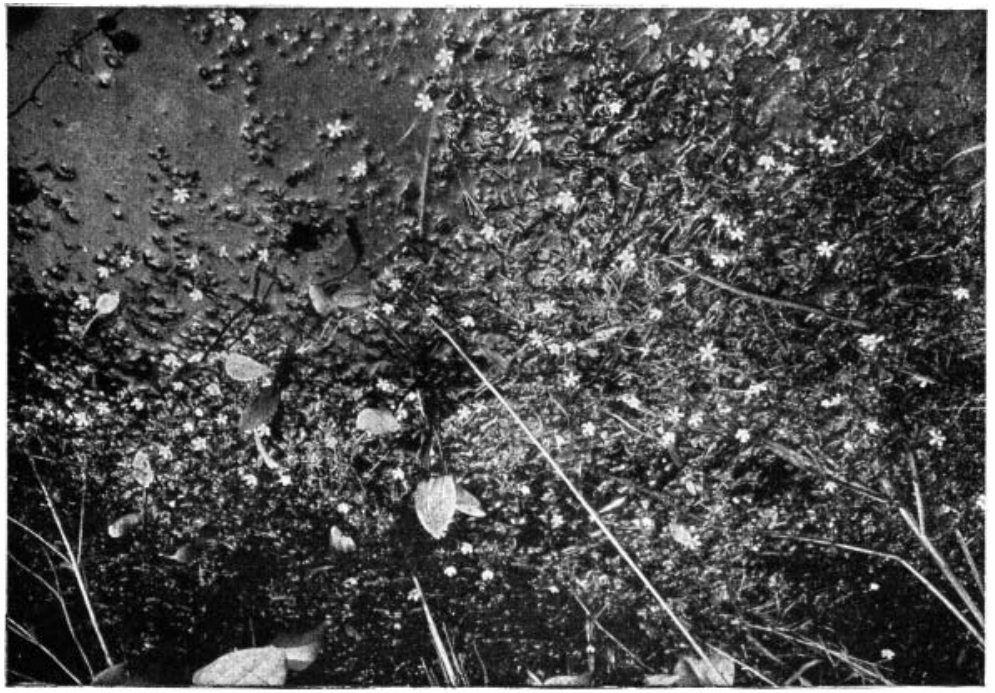

FIG. 203. A marshy pool with flowers of the white water crow-foot rising from the surface. 
joint weed (Polygonum) and the buck-bean (Menyanthes trifoliata). True climbers also, are present in the marsh although usually only on its borders; such are the climbing nightshade bittersweet (Solanum dulcamara) and the beautiful fragrant-flowered climbing hemp-weed (Mikania scandens). Here and there one may see a protruding top of swamp dock (Rumex verticillatus), a water hemlock (Cicuta bulbifera) or a swamp milkweed (Asclepias incarnata).

Every opening in the marsh contains forms that are more characteristic of ponds and ditches, such as arrowheads and water plantain. And even the little trash filled pools often contain their submerged aquatics. Such a one is shown in the figure 203, a shallow pool filled with fallen leaves, its surface suddenly sprinkled over with little star-like flowers when the white watercrowfoot shoots up its blossoms.

Algæ often fill these pools; sometimes minute freeswimming forms that tint their waters, but more often "blanket algæ," whose densely felted mats may smother the larger submerged aquatics.

The animal life of the marsh is also a mixture of pond forms and of forms that belong to the more permanent waters. The fishes are bullheads and top minnows and others that can endure foul waters, scanty oxygen and rapid fluctuations of temperature. Of crustaceans, ostracods and scuds are most abundant. Of molluscs, Pisidium and Planorbis are much in evidence, and other snails are common. Insects abound. Some are aquatic and some live on the plants. Of all Odonata, Lestes (fig. 204) is perhaps the most characteristic marsh inhabitant; of mayflies, Blasturus and Cænis; stoneflies, there are none. Of caddis-flies there are many, but Limnophllus indivisus is perhaps the most characteristic marsh species. It is not known to inhabit any waters except 
those that dry up in summer. The commonest beetles are small members of the families Hydrophilidæ, Dytiscidæ and Haliplidæ. The most characteristic of

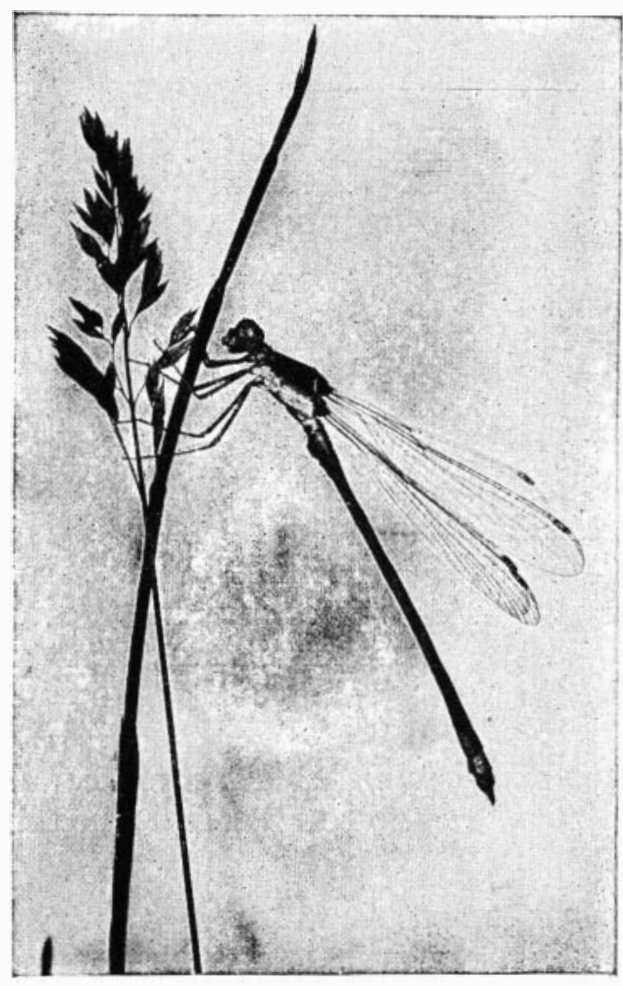

FIG. 204. A damselfly. Lestes uncatus. the bugs is the slender little marshtreader, Limnobates. Swale-flies, mosquitoes, craneflies and ubiquitous midges abundantly represent the aquatic Diptera.

There are, of course, many insects dependent upon particular plants. Such are the tineid moth, Limnacea phragmitella, that burrows when a larva in the Typha fruit spike, and the weevil, Sphenophorus, that burrows in the Typha crown; the leaf-beetle, Donacia emerginata, whose larva feeds on the submerged roots of the bur-reed, etc. Here are also a number of characteristic spiders, such as the diving spider, Dolomedes.

Doubtless the lower groups of animals possess species that are addicted to dwelling in marshes, and fitted to the peculiar conditions such places impose, but these 
have been little studied. There is hardly any situation where the fauna is so imperfectly known.

As compared with the land, fauna and flora of marshes are characterized by a small number of species, and enormous numbers of individuals. In other words,

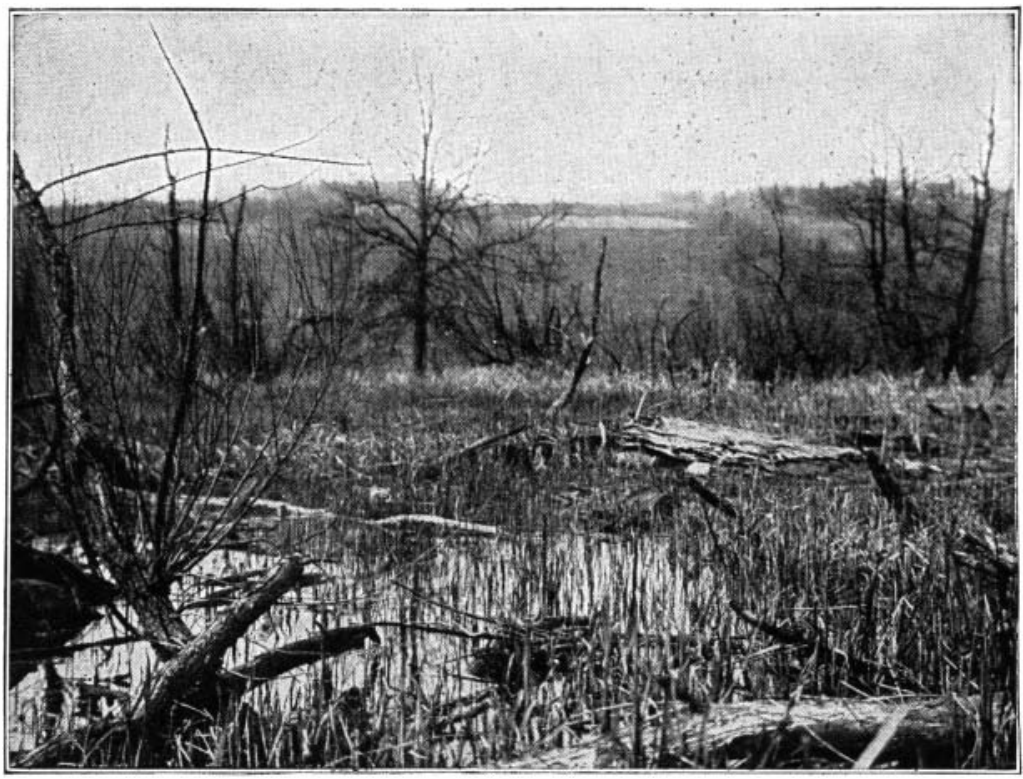

Fig. 205. "Tree-swallow pond": a once famous collecting ground in the Renwick marshes at Ithaca. Photo taken in spring after the burning and the freezing and the floods, but before the growth of the season.

the population is one of small variety but of great density. Such forms as are fitted to maintain themselves where floods and fire alternately run riot find in the rich soil and abundant light and moisture opportunity for a great development. Fire sweeps the surface clear of trees, which would overtop and overshadow the herbage and would create swamp conditions. The ground layer of water-soaked trash prevents the burn- 
ing of the root stocks; it also prevents deep freezing after the fires have run. Plants that are capable of renewing their vegetative shoots from parts below the level of the burning, are the ones that year after year, maintain their place in the sun.

\section{III}

Bog Societies. Bogs belong to moist climates and to places where water is held continuously in an amount sufficient to greatly retard the complete decay of plant remains. Acids accumulate, especially, humous acids. The soil becomes poor in nutriment, especially in available nitrogen. Plants can absorb little water, at least at low temperature; and the typical bog situation is therefore said to be "physiologically dry." With such conditions there go some striking differences in flora and fauna. The plants are "oxylophytes" like sphagnum and cranberry, i. e., plants that can grow in more or less acid media, and that have many of the superficial characteristics of desert plants; such as vestiture of hairs or scales or coatings of wax, thickened cuticle, leaves so formed or so closed together as to limit or retard transpiration. The kinds of plants are fewer; the individuals crowd prodigiously. They are eaten by animals less than in any other situation. Their remains, partly decomposed, are added to the soil in the form of deposits of peat. The animal population is correspondingly reduced and scanty.

Sphagnum. The most characteristic single organism in such a situation is the bog-moss, Sphagnum (fig. 206; see also fig. 59 on p. 147). This grows in cushion-like masses of soft erect unbranched stems, that are individually too weak and flaccid to stand alone, but that collectively make up the largest part of the bog cover. The masses are loose and easily penetrated by the roots 
and runners of other stronger plants. It is the interpenetration of these that binds the bog cover together, making it resilient under foot.

The leaves of Sphagnum are interspersed with cells that are mere water reservoirs having porous walls. Some of these leaves are deflexed against the stem and make excellent capillary conduits for water upward or downward. Whether the abundant supply be in the air above or in the soil below, these make provision for the equitable distribution of it. Wherefore, these masses of sphagnum become water reservoirs, holding their supply often against gravity, and bathing the roots of all the cover plants that rise above the surface of the bog.

Sphagnum belongs to the shore, and it is quite incapable of advancing into the water unassisted. But with
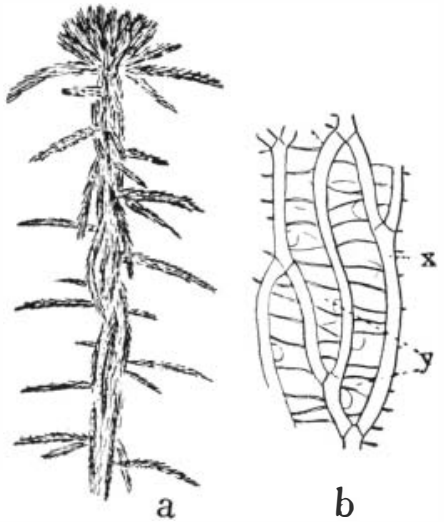

Fig. 206. Bog moss, Sphagnum;

$a$ the tip of a spray; $b$, a few cells from a leaf; $x$, long interlared lines of slen. der sinuous chlorophyl-bearing cells, and $y$, large empty water reservorr cells having pores in their walls for admission of water and annular cuticularisations for support. the help of stronger more straggling plants whose roots and branches penetrate and interlace in its masses in mutual support, it is able to extend as a floating border out over the surface of still water in small lakes and ponds. These floating edges may be depressed by the weight of a man until they are under water, but they are tough and elastic, and rise again unharmed when the weight is removed. Long, strong, pliant-stemmed heaths and slender sedges are the plants commonly associated with sphagnum in the making of this floating border. In the bog cover equally close is its association with the common edible cranberry. 
Some habitual associates of sphagnum are shown in figure 207. In such a place as the foreground of this picture, if one slice the bog cover with a hay-knife, he

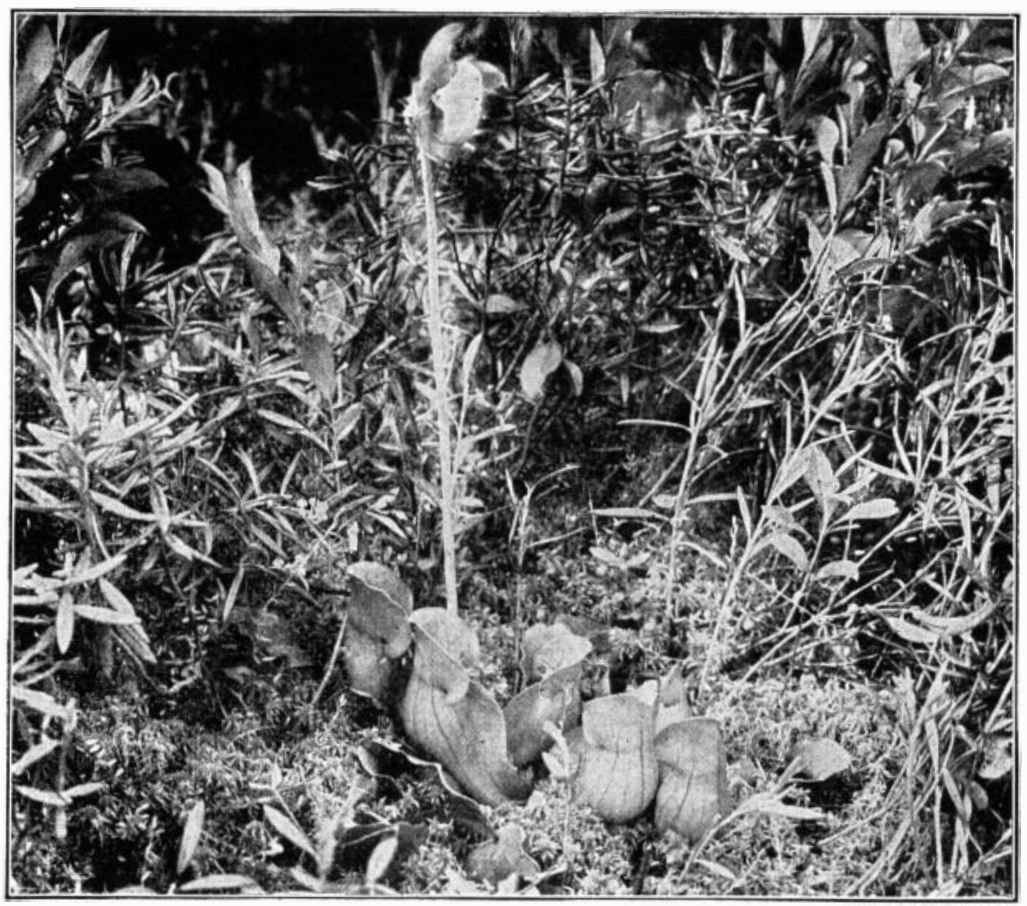

Fig. 207. A bit of bog cover. (McLean, N. Y.). From the central clump of pitcher-plant leaves rises one long-stalked flower. The surrounding bog moss is Sphagnum. A few slender stems of cranberry trail over the moss. The taller shrubs are mainly heaths such as Cassandra and Andromeda.

(Photo by H. H. Knight.)

may easily lift up the slices; for they are composed of living material to a depth of only about a foot. Below is peat; at first light colored and composed of identifiable plant remains, but, deeper, becoming darker and more completely disintegrated. The slices cut from 
the surface have sphagnum for their filling, but they are tough and pliant, like strips of felt, owing to the close interlacing of roots and stems of the other plants of the bog cover.

Many delightful herbs grow on the surface of the bog. The pitcher-plant shown in our figure is one, and the sundew (see fig. I 72 on p.

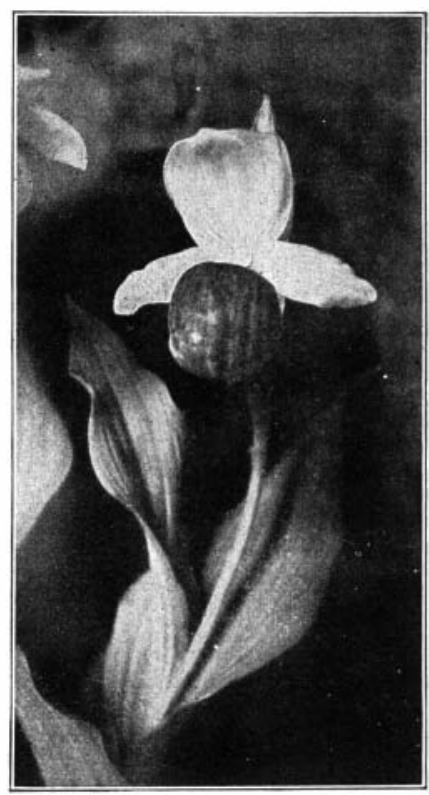

Fig. 208. A charming bog plant, the moccasin flower. (Cypripedium reginae). 283) is another carnivorous species. These, as we have seen in the preceding chapter, have their own way of getting nitrogen when theavailable supply is small. Orchids of several genera (Habenaria, etc.) and moccasin flowers (fig. 208) there bear beautiful flowers. Cotton grass (Eriophorum) is showy enough with its white tufts held aloft when in fruit, and a beaked rush (Rynchospora) is its natural associate. In places where the surface rises in little hummocks, there are apt to be patches of the xerophytic moss, Polytrichium, associated with charming little colonies of wintergreen and goldthread. At the rear of the heath shown in our figure stand huckleberries and bog brambles and masses of tall bog ferns while thickets of alder and dogwood crowd farther back.

Where sphagnum borders on open water, there often lies in front of it the usual zone of aquatics with floating leaves, as shown in the accompanying picture, and in 
still deeper water there are apt to be beds of Chara and of pondweeds. These and the molluscs associated with them, leave their calcified remains deposited on the pond bottom as a stratum of marl. Thus the

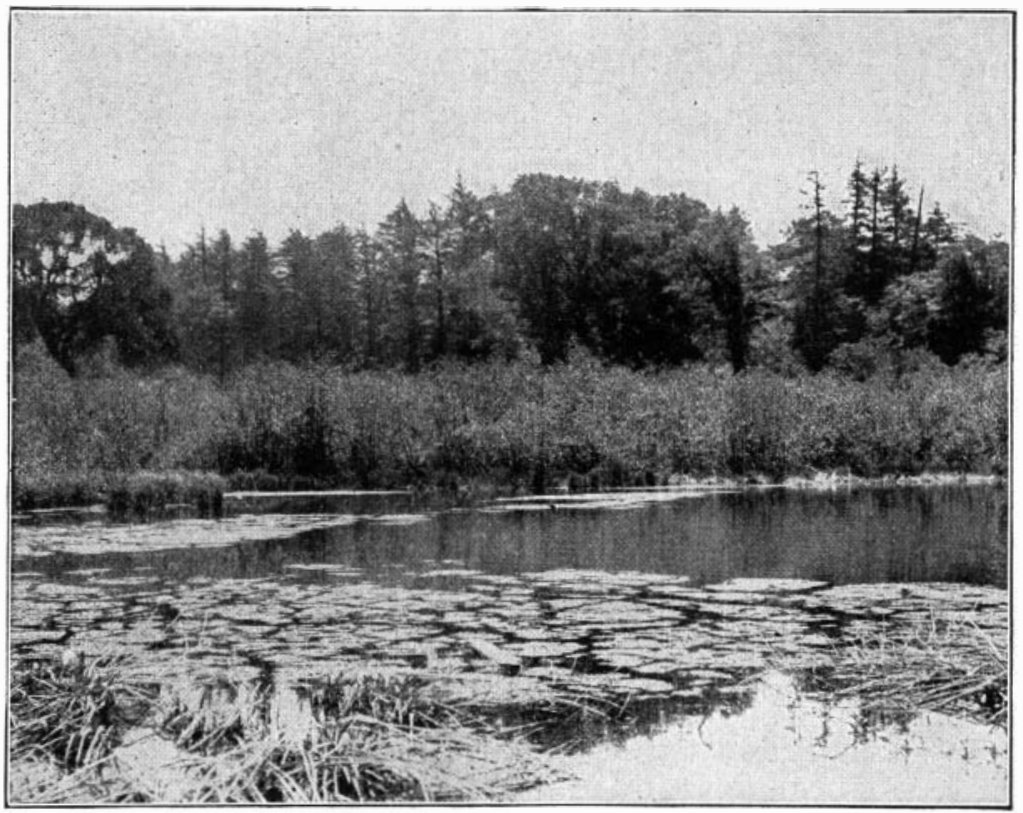

FIG. 209. Mud pond, near McLean, N. Y. This is a bog pond, surrounded in part at least by floating sphagnum. The outlet (to left in the picture) is bordered by tussock sedges, backed up by extensive alder thickets.

(Photo by John T. Needham.)

filling of a bog pond is in time accomplished by the deposition of a layer of marl over its bottom, and a much thicker mass of peat over the marl. Successive stages in the filling process are graphically shown in Dachnowski's diagram, copied on the next page.

Peatformation and filling of beds goes on, of course, in ponds where there is no sphagnum; goes on wherever 
the conditions for incomplete decay of plants prevail; and from the foregoing it will be seen that peat is not likely to be composed of the remains of sphagnum alone. The forefront of advancing shore vegetation is led by a number of plants of very different character.
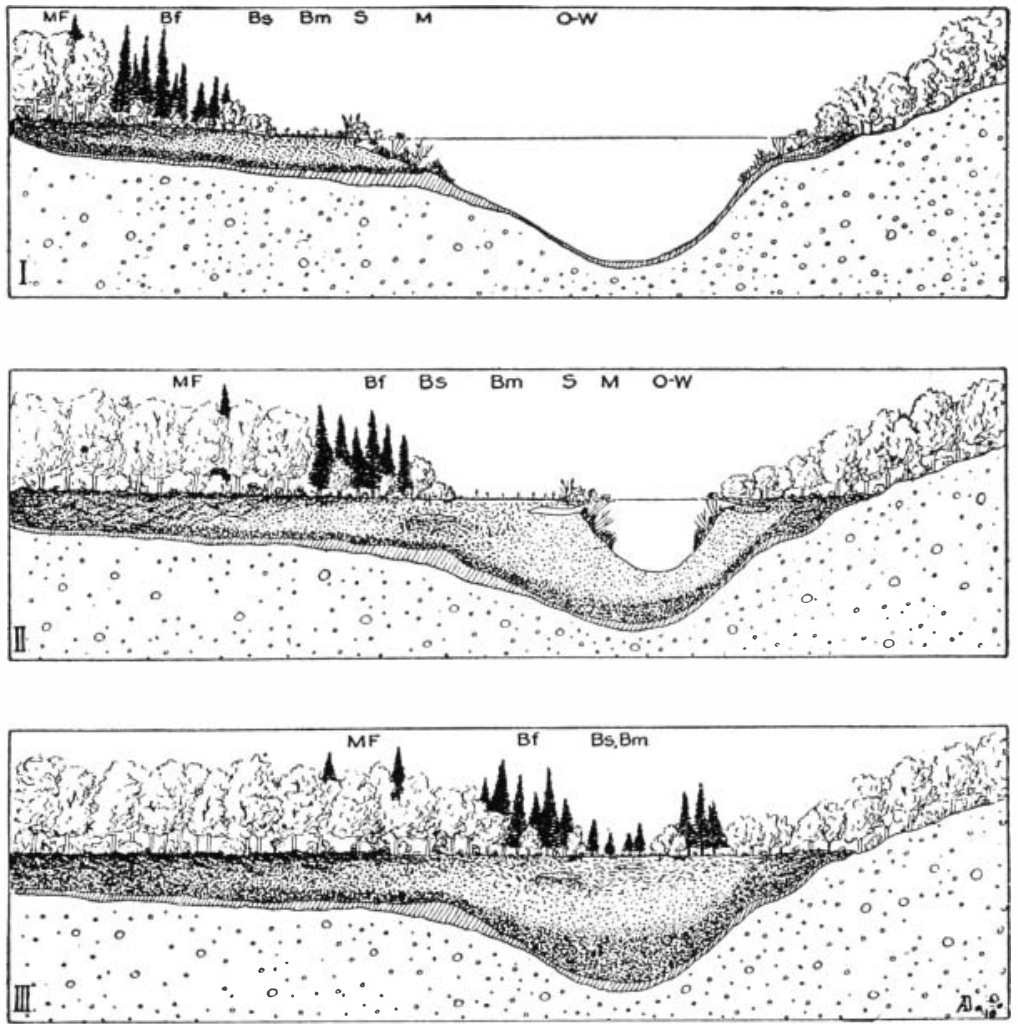

Fig. 210. Dachnowski's diagram illustrating three stages in the filling of a pond with deposits of peat and marl. Peat is stippied; marl, cross-lined.

OW, open water; M, marginal succession; $S$, skore succession; B, bog succession, including bog meadow (Bm), bog shrub (Bs), and bog forest (Bf); MF, mesophytic forest. 


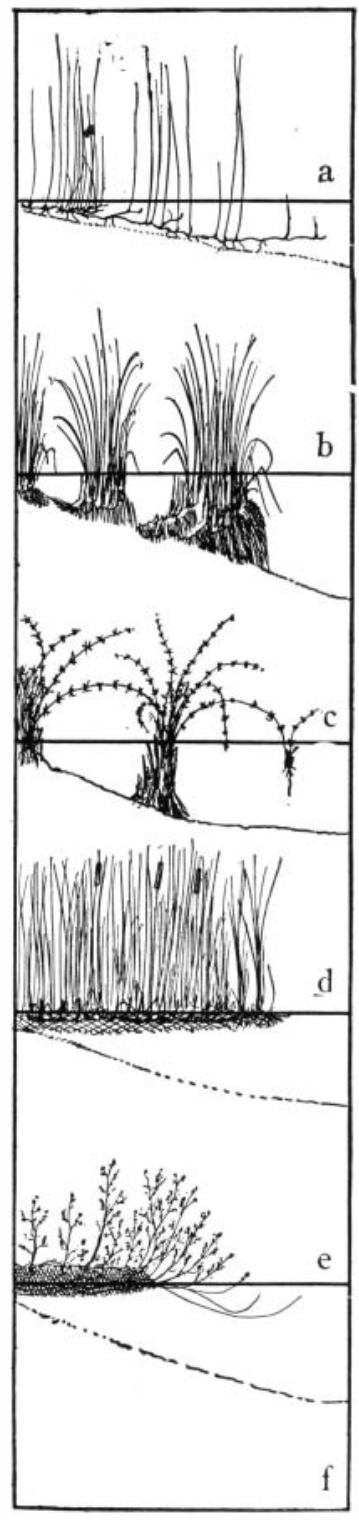

The accompanying diagram shows five modes of progress into deeper water of pioneer landbuilding plants.

$a$ is the method of the spikerush on gently sloping shore. It is the method by which numberless shore plants extend their holdings, - subterranean off-shoots.

b is the method of the tussock sedges (see also fig. 209) which on the loose mud in shallow waters build up solid clumps. Many of these, less than a foot in diameter, are yet of such firmness that they will sustain the weight of a man. Every one knows such clumps, from having used them (as stepping stones are used) in crossing a swale. New offsets lie hard against the old ones, roots descend in close contact, and fibrous rootlets interlace below in extraordinary density.

c is the method of the swamp loosestrife, Decodon, a method of advancing by long single strides. The tips of the long over-arching shoots dip into the water, and then develop roots and buds and a copious envelope of aerating tissue. If these new roots succeed

FIG. 2II. Diagram illustrating the method of advance into deeper waters of typical landbuilding plants.

a. Spike rush; b, tussock sedge; c, swamp loosestrife; d, cat-tail flag; e, Sphagnum and hea th s. 
in taking a good hold on the bottom, then other shoots spring from this new center and repeat the process.

$\mathrm{d}$ is the method of the cat-tail flag. It consists in developing an abundance of interlaced fibrous roots, and then simply floating on them. Much mutual support is required by plants that grow so tall; and any great advance of a few clumps beyond the general front may result in disaster from overturn by winds.

$\mathrm{e}$ is a method of mutual support between species of very different sorts. It is that of the sphagnum and heaths just discussed. Greater progress over deep water is made by this method than by any of the others.

A photograph of the first named is reproduced as figure 2I 2.

Fig.212. A bit of running root-stock of a spike rush. Eleocharis palustris, showing its method of advanceover the pond bottom. Branching subterran ean off-shoots extend down a sloping shore until they reach a depth of water in which they cannot function effectively.

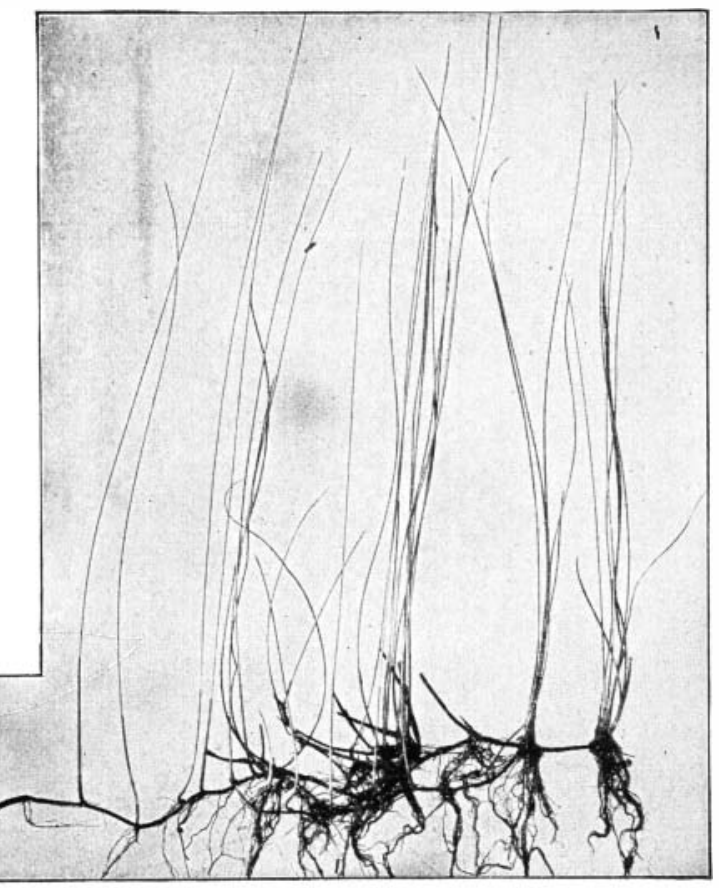




\section{IV}

The population of stream beds-If we distinguish between lenitic and lotic societies by presence or absence of growths of vascular plants, then the greater part of stream beds shelter lenitic societies. The greater part has not a current of sufficient swiftness to prevent the growth of such plants. And indeed it is only in restricted portions of any stream that we find the animals specially adapted to meet conditions imposed by currents.

Where the stream bed forms a basin, there the conditions of life, for the larger organisms at least, approximate those of a lake. Hence we find in those places in large streams where the water is deep and still, there occur many forms like those in lakes. The sturgeon belongs in both, and so do the big mussels and the operculate snails, the big burrowing mayflies, the big tube dwelling midge larvæ, etc. The basins of creeks offer conditions like those in ponds; the basins of brooks, conditions like those of pools. And the largest species are restricted to such of the larger basins as can afford them adequate pasturage and suitable places for rearing their young. To be sure, in all those basins, the water is constantly passing on down stream and the plancton of the basin, while in part developing there, is in a large part constantly lost below and constantly renewed from above. Kofoid (08) states that "The plancton of the Illinois River is the result of the mingling of small contributions by tributary streams, largely of littoral organisms and the quickly growing algæ and flagellates, and of the rich and varied plancton of tributary backwaters, present in an unusual degree in the Illinois because of its slightly developed floodplain, and from which it is never entirely cut off, even at lowest water. $* * * *$ To these elements is added such further development of the contributed or indigen- 
ous organisms as time permits, or the special conditions of nutrition and sewage contamination facilitate. Though continually discharging, the stream maintains the continuous supply of plancton, largely by virtue of the reservoir backwaters-the great seedbeds from which the plancton-poor but well fertilized contributions of tributary streams are continuously sown with organisms whose further development produces in the Illinois River a plancton unsurpassed in abundance."

Doubtless, in every stream the plancton supply is constantly renewed from sheltered and well populated basins, which serve as propagating beds. And, indeed, on every solid support diatoms are growing, and the excess of their increase is constantly being released into the passing current. In the swiftly flowing, plancton-poor streams about Ithaca there is not time for much increase of free planctons by breeding. The waters run so swift a course they can only carry into the lake such forms as they have swept from their channels in their rapid descent.

While there has been much study of the life of the open waters of rivers there has hitherto been little study of their beds. Where the beds are sandy with flow of water over them we know the life differs from that of muddy basins. The heavier-shelled mussels and snails are on the sand; and the commoner insects there are the burrowing nymphs of mayflies and Gomphine dragon-flies, and the caddis-worms that live in portable tubes of sand.

The beds of the smallest streams are easy of access, and a few observations are available to indicate that their study will bring to light some interesting ecologica! relations. A few very restricted situations will be cited in illustration. 


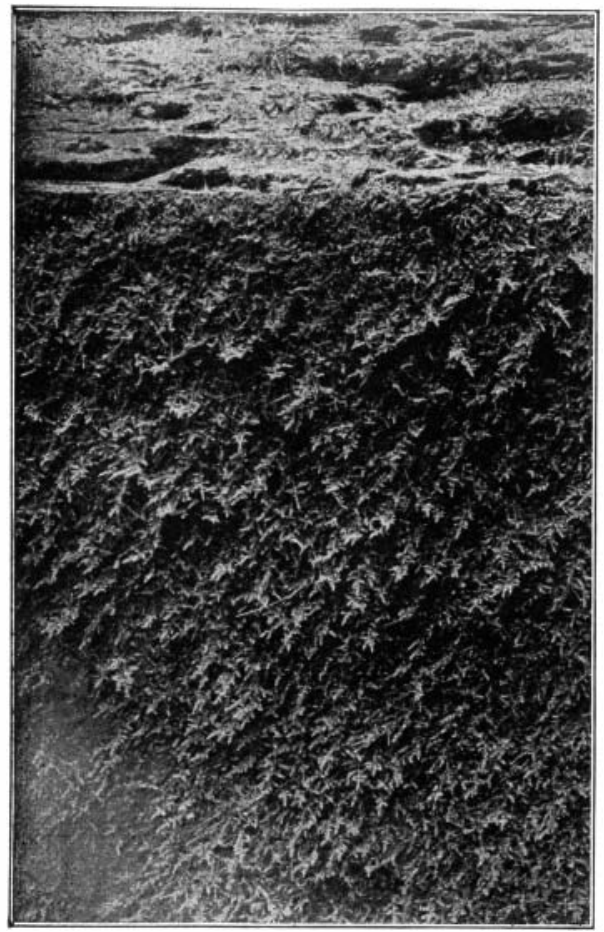

FIG. 213. A moss-bed covering the face of a rock ledge (in flood time, a waterfall) in the bed of Williams Brook at Ithaca, N. Y. The water seen on the rock above trickles down through this moss. Here is a restricted and peculiar animal population.

Moss patches-On the rocky beds of large brooks that run low but do not entirely run dry, there are frequent patches of the close-growing m o s s, Hydrohypnum. These patches frequently cover the vertical face of a waterfall (fig. 2I3). The little water that remains in dry season trickles through the layer of moss, and in times of flood the speedier torrent jumps over it. Under the flattened frondlike green sprays there is comparatively quiet water at all times; and in this situation there lives a peculiar assemblage of insects that differ utterly from the lotic forms dwelling in the same streams (to be discussed in a later part of this chapter), tho often dwelling within a few feet of them. They lack all the usual adaptations for meeting the wash of currents. They are (with occasional intermixture of a few larvæ of small midges and of Simulium) the following: 
I. The slender larvæ of soldier-flies (Euparhyphus brevicornis). Each bears a pair of ventral hooks that may serve for attachment.

2. The greenish larvæ of the cranefly (Dicranomyia simulans).

3. The warty-backed larvæ of the Parnid beetle (Elmis quadrinotatus).

4. Larvæ and pupæ of a little black Anthomyid fly (Limnophora sp.?).

$\begin{array}{lll}a & b & c\end{array}$

$d \quad e$

f $\quad g$

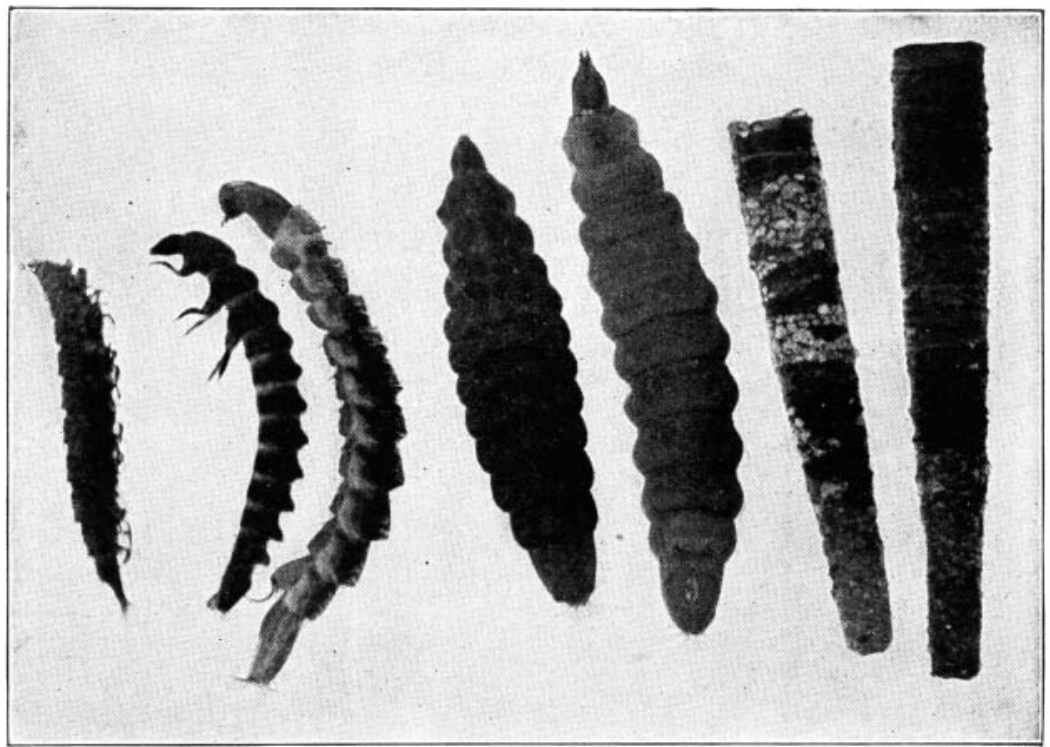

Fig. 2I4. Insect larvæ from a moss patch such as is shown in the preceding figure. $a$, Psychoda; $b$, Elmis; $c, d, e$, Euparhyphus, $c$, being lateral, $d$, dorsal and $e$, ventral views, $c$ and $e$ show the huge ventral hooks on the penultimate segment; $f$ and $g$, cases of an unknown caddis-worm, $f$, composed mainly of sand; $g$, mainly of moss. 
5. The slender larvæ of a moth fly (Psychoda alternata), its body covered with deflexed spines.

6. The larvæ of an unknown caddis-fly whose cases are composed sometimes of stones, sometimes of moss

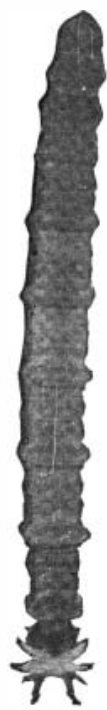

FIG. 2 I5. Two larvæ of the giant cranefly, $T i p$ ula abdominalis, an inhabitant of leaf-drifts in woodland brooks.

Natural size. fragments.

Leaf-drifts - In the beds of woodland brooks, there are barriers of fallen leaves, piled by the current upon the bare, obtruding roots of trees. These leaf-drifts have a population of their own, the most charactertistic member of which about Ithaca is the huge larva shown in figure 2I5. This is the larva of the giant cranefly, Tipula abdominalis. Associated with this larva in these water-soaked masses of leaves, are the nymphs of such stoneflies as Nemoura and of such mayflies as Bætis and Leptophlebia, a few beetles and often many scuds (Gammarus). In the mud behind the leaf-drifts, there are often earthworms, washed down from fields above.

In the clear pools in upland streams that flow through swampy woods, when the bottom is strewn with forest litter intermixed with brownish silt, there dwell a number of forms that certainly belong to thelenitic rather than to the lotic societies. Such are thecaddisworms of figure 2I6. With these are associated small mussels of the genus Sphærium, squat dragonfly nymphs of the genus Cordulegaster, and climbing nymphs of the genus Boyeria, water-skaters on the 
surface and burrowing mayflies in the beds, and a considerable variety of the lesser midges on every possible support.

We have already noted (page 86) that slack water exists behind boulders and other obstructions in the bed of rapid streams: but this is not stagnant water; and the animals living in such shelter, if the current above them be swift, are hardly ever of the same species that are found in ponds. Only in slow-flowing waters, where conditions merge, do lotic and lenitic forms become near neighbors.

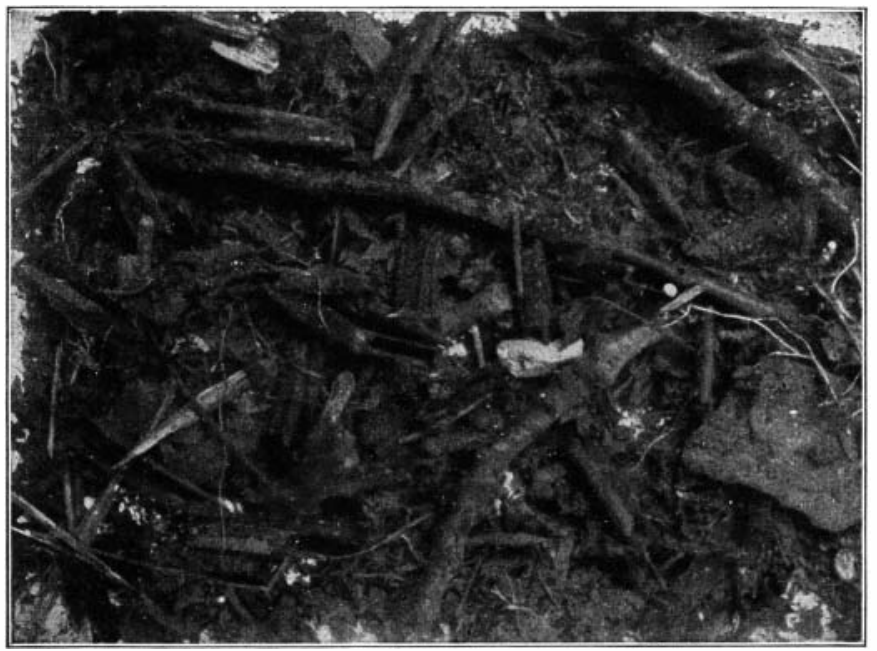

FIG. 2I6. A bit of the bed of a pool in a woodland stream showing among the forest litter the wooden cases of the larva, of the caddis-fly, Halesus guttifer. (See also fig. I04 on p. I98.) Protective resemblance. There are $\mathbf{1} 4$ cases in the picture. 


\title{
A DIAGRAM OF LOCALIZATION OF INSECTS IN THE BED OF A SWIFT STREAM
}

(From Needham and Christenson, '27)

\author{
surface
}

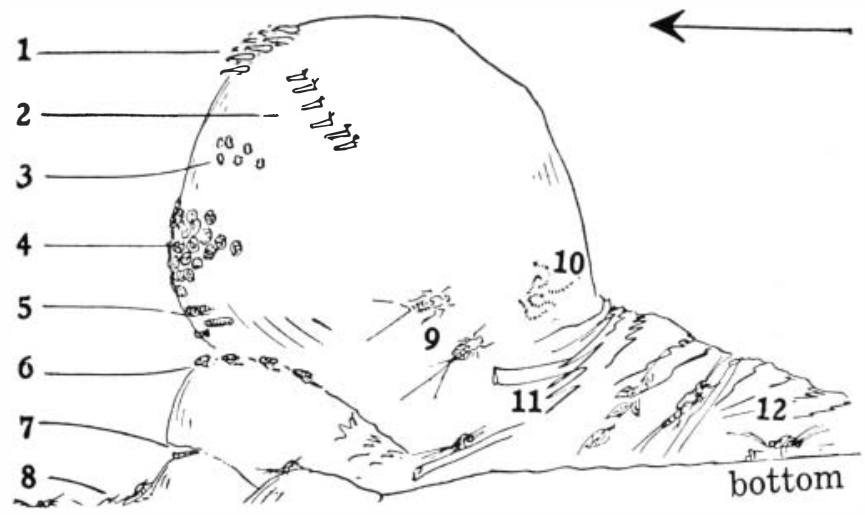

Twelve situations about a boulder, and the insects commonly found in them in Logan River, Utah, are as follows:

I. Simulium; black fly larvae; fully exposed where current is swiftest.

2. Brachycentrus; caddis worms; in square cases attached by the upstream end.

3. Bibiocephala; net-winged midge-larvae; of limpet-form, adhering by ventral suckers.

4. Glossosoma; caddis worms, in pebbly cases on down-stream face of boulders.

5. Antocha; carnivorous cranefly larva; in tubes on down-stream face of boulder.

6. Hydropsyche; net-spinning caddis worm, making nets beside a crevice where water breaks over.

7. Atherix; snipe fly larva, living in crevices.

8. Baetis and Leptophlebia; mayfly nymphs, living on bottom in slackened current.

9. Iron and Rithrogena; mayfly nymphs, clinging to broad surfaces, mostly underneath.

Io. Chironomus and Tanytarsus; midge larvae, living in tubes in more or less exposed places.

II. Ephemerella grandis, the prickle-back mayfly nymph; clinging to trash in half sheltered places.

I2. Acroneuria and Pteronarcys; stonefly nymphs; living amid the trash and sheltered by it.

The arrow indicates direction of the current. 


\section{LOTIC $S \mathbb{C} \mathbb{I} \mathbb{E} \mathbb{T} \mathbb{E}$}

CCORDING to the grouping outlined on page 3 I5, we designate by this name those assemblages of organisms that are fitted for life in rapidly moving water - that are washed by currents, as the name signifies. Whether the water flow steadily in one direction as in streams, or back and forth with frequent shifts of direction as on wavewashed shores, the organisms present in it will be much the same sorts. The plants will be mainly such algæ as Cladophora, and slime-coat diatoms: the animals will be mainly net-spinning caddis-worms and a variety of more or less limpet-shaped invertebrates.

The animals of lotic societies are mainly small invertebrates. There are fishes, indeed, like the darters that live in the beds of rapid streams. These lie on the bottom where the current slackens, lightly poised on their large pectoral fins, or rest in the lee of stones, darting from one shelter to another. It is only a few 
lesser animals, of highly adapted form and habits, that are able to dwell constantly in the rush of waters.

These lesser animals may be roughly divided into two categories according to the sources of their principal food supply:

I. Plancton gathering forms, that are equipped with an apparatus for straining minute organisms out of the open current.

2. Ordinary forms that gather home-grown food about their dwelling places.

I. Plancton Gatherers.-These are they that live mainly on imported food, which by means of nets or baskets or strainers they gather out of the passing current. These are the most typical of lotic organisms, for they must needs live on the exposed surfaces that are washed by the current. They dwell on the bare rock ledge, over which the water glides swiftly, or on the top of the boulders in the stream bed, or on the exposed side of the wave-washed pier. They are few in kinds, and very diverse in form, and show many signs of independent adaptation to life in such situations. Among them are four that occur abundantly in the Ithaca fauna. These four and their mode of attachment and of plancton gathering are illustrated in the accompanying diagram. The fly larva, Simulium, adheres by a caudal sucker, gathers plancton by means of a pair of fans placed beside its mouth, while its body dangles head downward in the stream. The larva of the caddis-fly, Hydropsyche, lives in a tube and constructs a net of silk that strains organisms out of the water running through it. The caddis-worm, Brachycentrus, attaches the front end of its case firmly to the top of a boulder in the stream bed, and then spreads its bristle-fringed middle and hind feet widely to gather in any organisms that may be adrift in the passing water. 
The nymph of the "Howdy" Mayfly, Chirotenetes, fixes itself firmly with the stout claws of its middle and hind feet clutching a support, and extends its long fore feet with their paired fringes of long hair outspread like a basket to receive what booty the current may bring. These four are so different they are better considered a little further separately.

The larva of Simulium (the black-fly, or buffalo gnat) perhaps the most wide-spread and characteristic animal

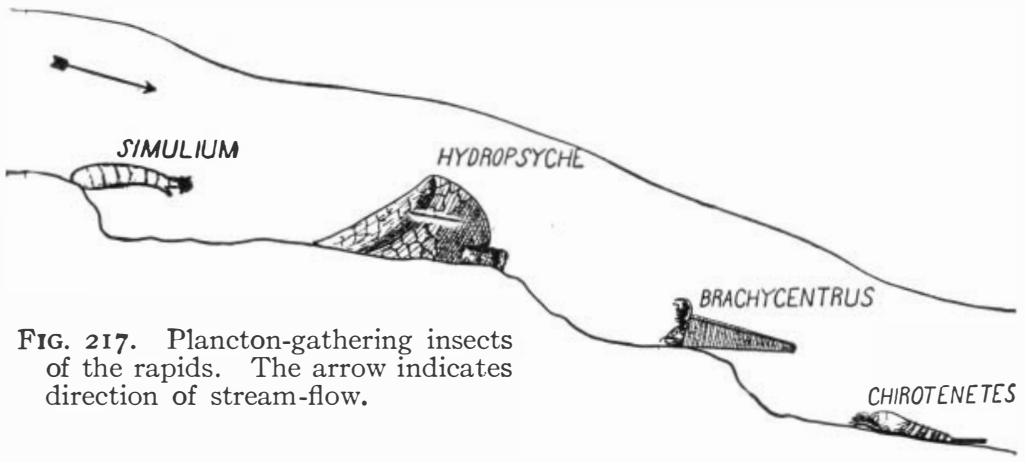

of running water, is unique in form and in habits. It hangs on by means of a powerful sucker that is located near the caudal end of its soft and pliant bag-shaped body. But it may also attach itself to the stones by a silken thread spun from its mouth: and if it then loosens its sucker, it will dangle at the end of the thread, head upstream. By means of these two attachments, it may travel from place to place without being washed away, but in the swiftest water, it can make only short moves sidewise. It travels by loopings of its body, like a leech. So it shifts its location with changes of water level, always seeking the most exposed ledges which a thin sheet of water pours over. There it gathers in companies, so closely placed side by side as to form great black patches on the stones. 
There is little movement from place to place. The larvæ hang at full stretch, their pliant bodies swaying with little oscillations of the current, their fans outspread, straining what the passing stream affords. Each of these fans is composed of several dozen slender rays, each one of which is toothed along one margin like a comb of microscopic fineness, and all have a parallel curvature like the fingers of an old-fashioned reaper's cradle. They are efficient strainers.

When grown the larva spins its half cornucopiashaped straw-yellow cocoon on the vertical face of a ledge where the water will fall across its upturned open end, then transforms to a pupa inside. The pupa bears on the prothorax a pair of long, conspicuous, many branched respiratory horns, or "tube gills" (see fig. I7 I on p. 280).

The eggs are laid at the edge of the swiftly flowing water on any solid support, on the narrow strip that is kept wet, and, by oscillations of the current occasionally submerged.

Hydropsyche, the seine making caddis-worm, lives in sheltering tubes of silk, spun from its own silk glands, fixed in position on the surface of a stone (oftenest in some crevice), and covered on the outside with attached sticks or broken fragments of leaves or stones. Always one end of the tube is exposed to the current, and at this end, the larva reaches out to forage. Here it constructs its net of crosswoven threads of fine silk. The net is a more or less funnel-shaped extension of silk from the front of the dwelling-tube. The opening is directed upstream, so that the current keeps it fully distended. The semi-circular front margin is held in place by means of extra staylines of silk. The mesh is rather open on the sides, but on the bottom there is usually a small feeding surface that is much more closely woven. 
The larva lies in its tube in readiness to seize anything the current may throw down upon its feeding surface or entangle in the sides of its net. The whole net is so delicate that it collapses on removal from the water. To see it in action, it is best examined through a "water-glass."*

Brachycentrus, the "Cubist" caddis-worm, is restricted in habitat to spring-fed streams flowing through upland bogs. It constructs a beautiful case that is square in cross-section. Each side is covered with a single row of sticks (bits of leaf stalks, grass stems, etc.) placed crosswise. The larva fastens its case by a stout silken attachment to the top of sorne current-swept boulder and then rests with legs outspread as indicated in figure $2 \mathrm{I} 7$ in a receptive attitude, waiting for whatever organic materials the current may bring within its grasp.

The Nymph of Chirotenetes, the "Howdy" Mayfly, lives on the rock ledge or where the water sweeps among the stones. Its body is of the stream-line form discussed in the last chapter-the form best adapted to diminishing resistance to the passage of water, as well when at rest as when swimming. The nymph sits firmly on its middle and hind feet. Holding its front feet forward, it allows the current to spread out their strainer-like fringes of long hairs. These retain whatever food is swept against them, and the mouth of the nymph is conveniently near at hand. It uses its feet for standing but moves from place to place by means of swift strokes of its finely developed tail fin, supplemented by synchronous backward strokes of its strong tracheal gill covers. It has almost the agility and swiftness of a minnow.

\footnotetext{
*A "water-glass" is any vessel having opaque sides and a glass bottom, of convenient size for use. An ordinary galvanized water pail with its bottom replaced by a circular glass plate set nearly flush, is exccllent.
} 
2. Ordinary Foragers. - These are the members of lotic societies that lack such specialized means of gathering food from the passing current, and that forage by more ordinary methods. They live for the most part on the sides of stones and underneath them, and not on their upper surfaces. These also live where the water runs swiftly, and, for the most part, out of the reach of those fishes that invade the rapids. There are two principal categories among them: $a$. Free-living forms that are more or less flattened or limpet-shaped. $b$. Shelter-building forms, that are in shape of bory more like the ordinary members of their respective groups.

The limpet-shaped forms are members of several orders of insects, worms and snails. Their flattened form and appressed edges are doubtless adaptations to life in currents. They adhere closely, and are on account of their form, less likely to be washed away; the current presses them against the substratum.

Not the most limpet-like but yet the best adapted for hanging on to bare stones in torrents is the curious larva of the net-veined midge, Blepharocera (see fig. I59 on p. 259), an inhabitant only of clear and rapid streams. The depressed body of this curious little animal is equipped with a row of half a dozen ventral suckers, each of which is capable of powerful and independent attachment to the stone. So important have these suckers become that the major divisions of the body conform to them and not to the original body segments. On these suckers, used as feet, the larva walks over the stones under the swiftest water, foraging in safety where no enemy may follow.

Most limpet-like in form of all is the larva of the Parnid beetle, Psephenus, commonly known as the 
"water-penny" (see fig. I60 on p. 260). It is nearly circular and very flat with flaring margins that fit down closely to the stone. It adheres closely and is easiest picked up by first slipping the edge of a knife under it. Viewed from above, it has little likeness to an ordinary beetle larvæ, but removed from the stone and overturned, one sees under the shell a free head, a thorax with three short legs, an abdomen and some minute soft white segmentally arranged tracheal gills on each side.

Other insect larvæ that have taken on a more or less limpet-like form, are the nymphs of certain Mayflies and of many stoneflies (fig. I I I on p. 204). The body is strongly depressed. The lateral margins of the head and thorax are extended to rest down on the supporting surface. The legs are broadened and are laid down flat so as to offer less resistance to the currents, and stout grappling claws are developed upon all the feet. Such is Heptagenia whose nymphs abound in every riffle and on every rocky shore.

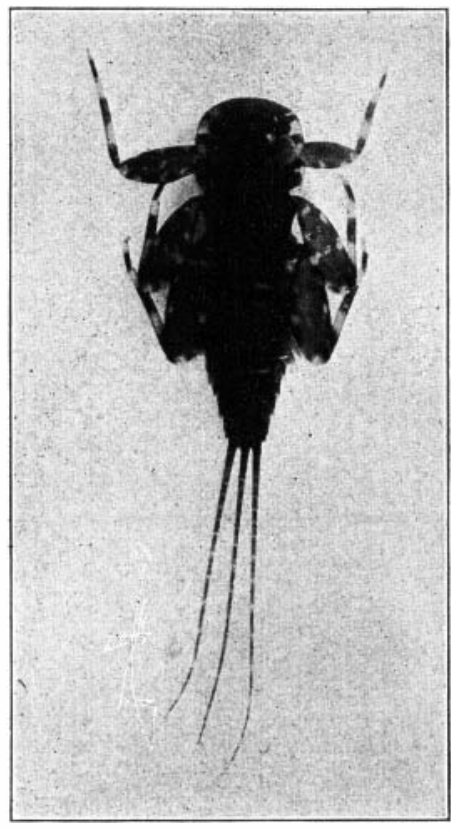

FIG. 2I8. The nymph of a mayfly (Heptagenia) from the rapids, showing depressed form of the body and legs.

(Photo by Anna H. Morgan.)

One may hardly lift a stone from swift water and invert and examine it without seeing them run with sidelong gait across its surface, outspread flat, and when at rest appearing as if engraven on the stone. 
The head is so flat and flaring that the eyes appear dorsal in position instead of lateral as in pond-dwelling Mayfly nymphs.

A more remarkable form is the torrent-inhabiting nymph of Rithrogena whose gills are involved in the flattening process. They also are flattened and extended laterally and rest against the stone. But,
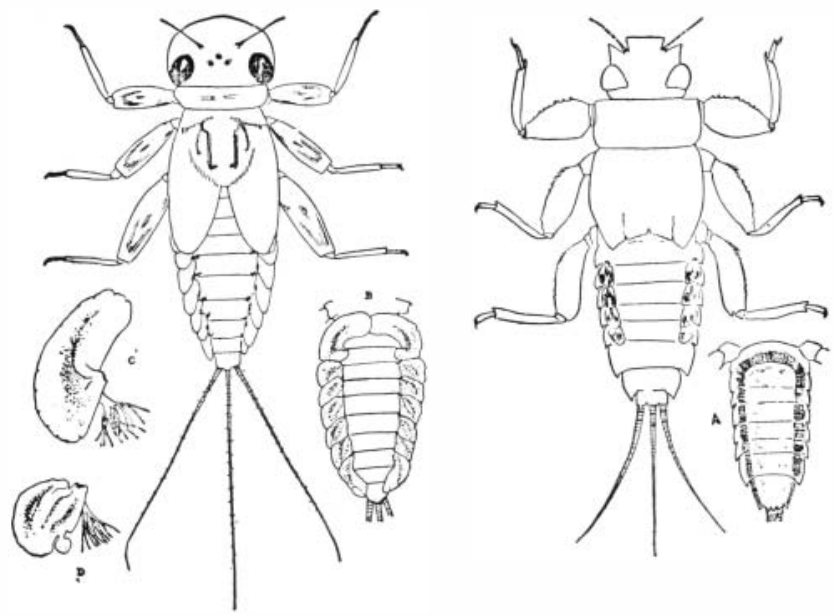

FIG. 219. Parallel development of limpet-like form of body in two mayflies. Right, the nymph of Ephemerella doddsi; $\mathrm{A}$, the overturned abdomen. Left, the nymph of Rithrogena mimus; $\mathrm{B}$, the overturned abdomen; $\mathrm{C}$, the foremost gill; D, the second gill. (Courtesy of the Utah Agricultural Experiment Station).

most remarkable of all, the anterior pair is deflected forward and the posterior pair, backward, to meet on the median line beneath the body, and both are enlarged and margined; By the close overlapping of all the gills of the entire series there is formed a large oval attachment-disc of singularly limpet-like form.

A similar flat attachment-disc is formed on the ventral side of the mayfly nymph shown in figure 219 , 
but on a wholly different plan. The gills are not involved in the disc, but instead the body itself is flattened and shaped to an oval form underneath, and fringed with close set hairs.

There is in the mayflies a rather close correlation between the degree of flattening of the body and the rate of flow of the water inhabited. It is well illustrated by the allies of Heptagenia; also by those of Ephemerella, among which occur swift-water forms. Epeorus, Iron and Rithrogena form an adaptive series. Among the Parnid beetles, Elmis (fig. 2 I 4b), Dryops and Psephenus (fig. I60) form a parallel series.

There are snails that dwell in the rapids. The most limpet-shaped of these is Ancylus (fig. I60 on page 260) whose widely open and flaring shell has in it only a suggestion of a spiral. Certain other snails (such as Goniobasis livescens) are of the ordinary form and are able to maintain themselves on the stones by means of a very stout muscular closely-adherent foot. Similarly, a number of flatworms, that adhere closely are found creeping in the rapids.

Shelter-building foragers are numerous in individuals but few in kinds. One tube-dweller, Hydropsyche, is a plancton gatherer and has been already discussed. There are other shelter building caddis-worms living among stones in running water. Ryacophila builds at close of larval life a barricade of stones as shown in the fig. I 25 on page $2 \mathrm{I} 7$, and shuts itself in

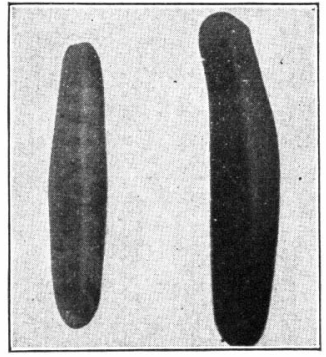

FIg. 220. Two pupal cases of the caddis-fly, Ryacophila, removed from the stones. and spins about itself a brownish parchment-like cocoon of the form shown in the accompanying figure. Helicopsyche constructs a spirally coiled case that is 
strikingly like a snail shell, and fastens it down closely in the shallow crevices of stones on exposed surfaces.
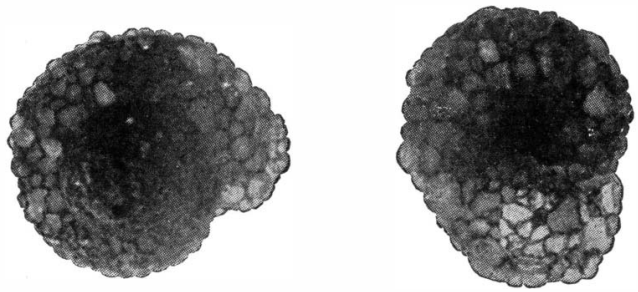

FIG. 22I. The spirally coiled cases of the caddis-worm, Helicopsyche.

A number of other caddis-worms build portable cases of sand and stones. Those of Gœra (fig. 222) are heavily ballasted by means of stones attached at the sides with silk. These lie down flat against the bottom

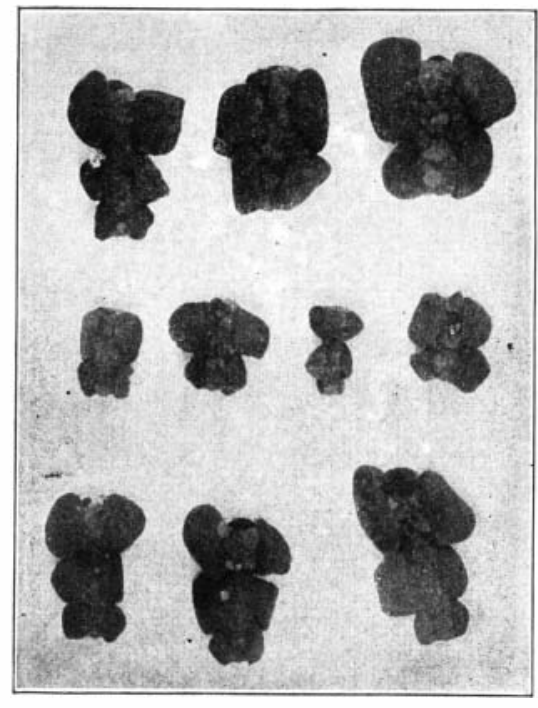

FIG. 222. Stone-ballasted cases of caddis-worms of the genus Gœra. and doubtless serve the double purpose of deflecting the current and preventing the case from being washed away.

The tubes of the midges are here made of less soft and flocculent materials than in still waters. Tanytarsus makes an especially tough case of a pale brownish color, likedried grass. It is of tapering form, and easily recognized by the three stay lines that run out from the open forward end. A small greenish yellow larva with rather long 
antennæ lives within, and protrudes its pliant length in foraging on the algal herbage that grows about its front door. And there are many other lesser midges whose larvæ dwell in silt - covered tubes on rocks in the rapids. Often they occur so commonly as to almost cover the surface.

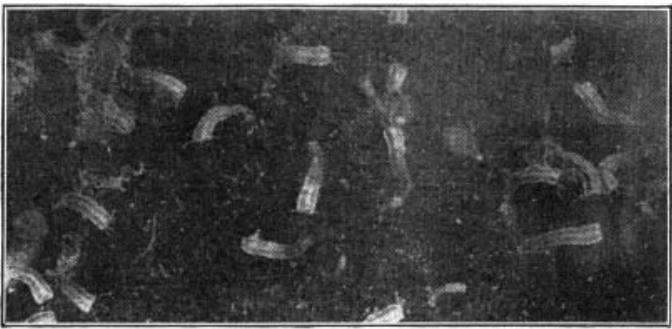

Fig. 223. Larval cases of the midge, Tanytarsus, attached to a stone in running water.

Shelters also limpet-shaped-It should be noted in passing that this flattened form, which is characteristic of so many members of lotic society, is characteristic not only of the living animals but also of their shelters. The tarpaulin-like web of the moth Elophila fulicalis is flat, and the pupal shelter is quite limpet-shaped. The case of Leptocerus ancylus is widely cornucopiashaped, its mouth fitted to the stone. The coiled case of Helicopsyche is a very broad spiral, closely

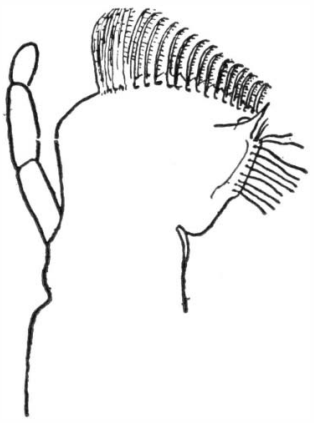

Fig. 224. The maxilla of a mayfly, Ameletus luaiens, showing diatom rake. 
attached in the hollows of stones and crevices of rock ledges. The case of the caddis-worm, Ithytrichia, (fig. I62 on p. 262) is broadly depressed.

Thus the impress of environment is seen not only in the form of a living animal but also in that of the non-living shelter that it builds. In this there is a parallel of form in the secreted shell on the back of the snail, Ancylus, and manufactured shell on the back of the caddis-worm, Helicopsyche. One would have to search widely to find better examples of the effects of environment in molding to a common form these representatives of many groups of very diverse structural types. Two of them, at least, were sufficiently like lotic mollusca to have deceived their original describers. Psephenus was first described as a limpet and Helicopsyche as a snail.

Foraging habits - The food of the herbivores in lotic societies is algæ. There are none of the higher plants

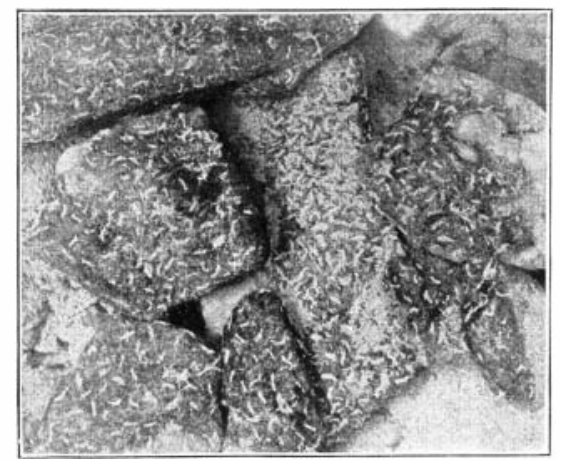

FIG. 225. The sheltering tubes of midge larvæ. Photographed under running water on the rocky bed of a stream. present, save a few mosses of rather local distribution. It is not surprising therefore that the food gathering apparatus of these forms should present special adaptative peculiarities. The mouth-parts of mayflies and of midges show much development of diatom rakes and scrapers. For scraping backward the labrum is often used. In the net-spinning caddis-worms it is bordered on either side by a stiff brush of bristles, and in midge 
larvæ there is developed both before and behind its border a considerable array of combs and rakers. In use the head is thrust forward, and these are dragged backward across the surface that supports the growth of diatoms and other algæ.

The principal carnivores of the rapids are the nymphs of stoneflies (see fig. I I I on p. 204) and a few small vertebrates. Among the latter are the insect-eating brook salamander, Spelerpes, and a number of small fishes, such as darters, dace and minnows.

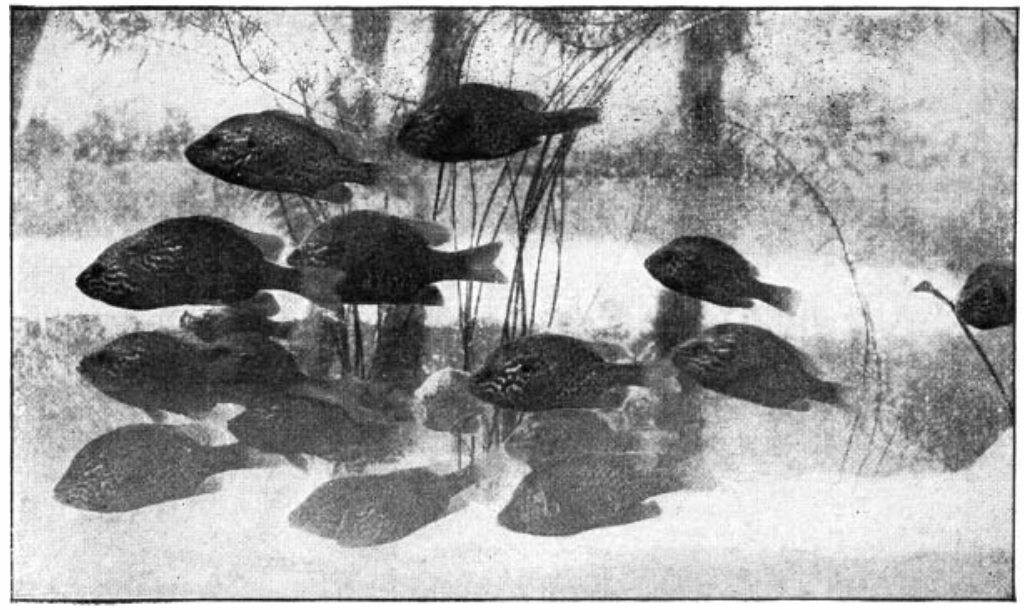




\section{THE TWO PRINCIPAL FISH ASSOCIATIONS \\ OF LAKE GEORGE, N. Y.}

From the senior author's Report on a Biological Survey of Lake George Courtesy of the New York State Conservation Commission

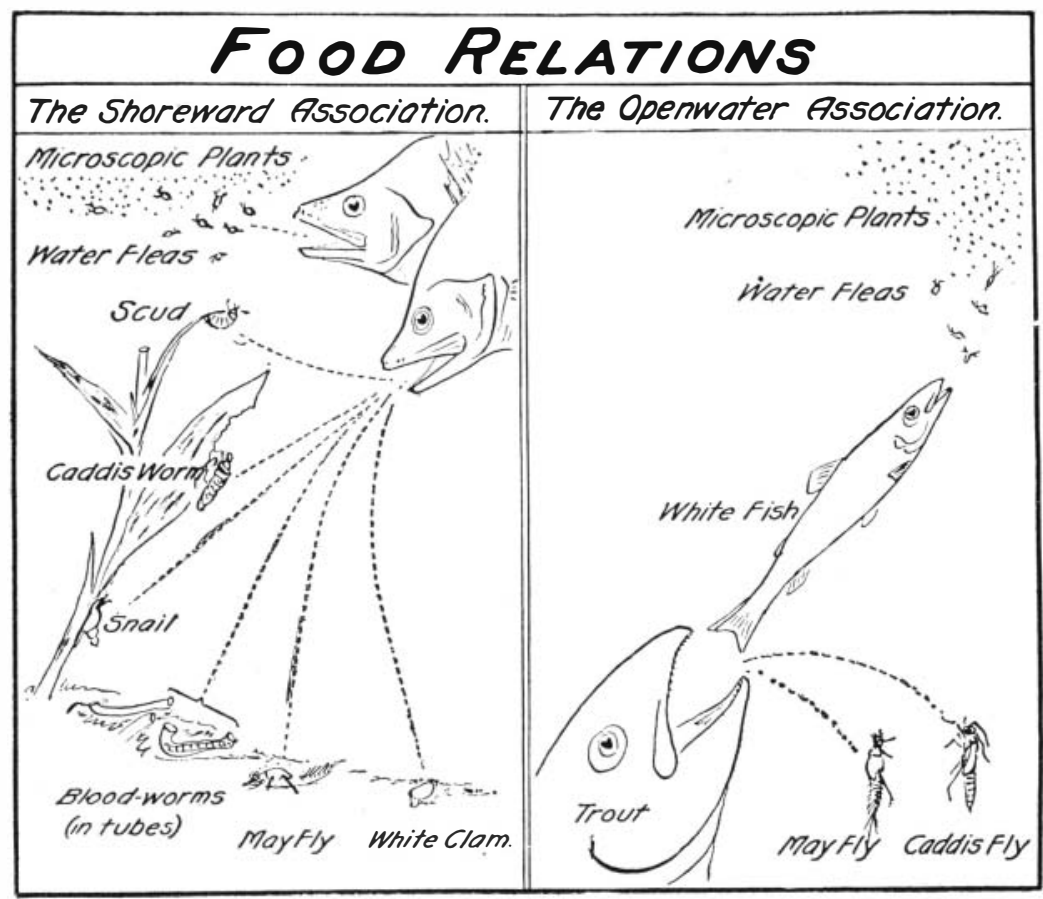

